\title{
Anti-inflammatory potential of mushroom extracts and
}

\section{isolated metabolites}

Oludemi Taofiq ${ }^{\mathrm{a}, \mathrm{b}}$, Anabela Martins ${ }^{\mathrm{a}}$, Maria Filomena Barreiro ${ }^{\mathrm{b}}$, Isabel C.F.R. Ferreira ${ }^{\mathrm{a}, *}$

${ }^{a}$ Mountain Research Centre (CIMO), ESA, Polytechnic Institute of Bragança, Campus de Santa Apólónia, 1172, 5301-855 Bragança, Portugal

${ }^{b}$ Laboratory of Separation and Reaction Engineering (LSRE), Associate Laboratory LSRE/LCM, Polytechnic Institute of Bragança, Campus de Santa Apolónia, 1134, 5301-857 Bragança, Portugal

* Author to whom correspondence should be addressed (e-mail: iferreira@ipb.pt telephone +351-273-303219; fax +351-273-325405). 


\begin{abstract}
Background: In the recent years natural resources are being in focus due to their great potential to be exploited in the discovery/development of novel bioactive compounds and, among them, mushrooms can be highlighted as alternative sources of anti-inflammatory agents.
\end{abstract}

Scope and approach: The present review reports the anti-inflammatory activity of mushroom extracts and of their bioactive metabolites involved in this bioactive action. Additionally the most common assays used to evaluate mushrooms anti-inflammatory activity were also reviewed, including in vitro studies in cell lines, as well as in animal models in vivo.

Key findings and conclusions: The anti-inflammatory compounds identified in mushrooms include polysaccharides, terpenes, phenolic acids, steroids, fatty acids and other metabolites. Among them, polysaccharides, terpenoids and phenolic compounds seem to be the most important contributors to the anti-inflammatory activity of mushrooms as demonstrated by numerous studies. However, clinical trials need to be conducted in order to confirm the effectiveness of some of these mushroom compounds namely, inhibitors of NF- $\kappa$ B pathway and of cyclooxygenase related with the expression of many inflammatory mediators.

Keywords: Inflammation; NSAIDs; Mushrooms; Bioactive compounds

\title{
Contents
}

1. Introduction

2. Inflammatory mediators and cell signalling

3. NSAIDs and their mechanism of action

4. Methodologies for anti-inflammatory potential screening 4.1 In vitro assays 

4.1.1 Nitric oxide assay
4.1.2 Cytokine enzyme linked immunosorbent assay (ELISA)

4.1.3 COX-1- and COX-2-Catalyzed Prostaglandin Biosynthesis Assay 4.2 In vivo studies

5. Mushroom metabolites with reported anti-inflammatory activity

5.1. The anti-inflammatory potential of mushroom extracts

5.2 Polysaccharides

5.3 Terpenes

5.4 Polyphenols

5.5 Steroids

5.6 Other metabolites

5.7 Commercial and synthesised compounds

6. Concluding remarks

Conflict of Interest

Acknowledgements

References 


\section{Introduction}

Inflammation is a physiological response to injury, characterised by loss of function and pain, heat, redness and swelling. It is usually associated with the pathogenesis of diseases such as diabetes, arthritis, obesity, metabolic syndrome, cancer and several cardiovascular diseases (Bellik et al., 2012; Moro et al., 2012; Ma, Chen, Dong, \& Lu, 2013).

An immune stimulant causes the pro-inflammatory cells, such as macrophages and monocytes, to start to secrete a number of inflammatory mediators such as interleukins (IL $1 \beta$, IL-6, IL-8), tumor necrosis factor (TNF- $\alpha)$, nuclear factor- $\kappa \mathrm{B}(\mathrm{NF}-\kappa \mathrm{B})$, intercellular adhesion molecule-1 (ICAM- 1), inducible type cyclooxygenase-2 (COX-2), prostaglandin E2 (PGE2), 5-lipoxygenase (5-LOX), and inducible nitric oxide synthase (iNOS) (Moro et al., 2012; Choi et al., 2014a; Taofiq et al., 2015). Uncontrolled production of these inflammatory mediators has been known to cause several cell damage and also initiate the inflammation process (Kanwar, Kanwar, Burrow, \& Baratchi, 2009).

Natural products are good resources for development of therapeutic compounds with antiinflammatory potential and without or lower toxic effects (Yuan, Wahlqvist, He, \& Yang, 2006). Several bioactive compounds from plants (Wang et al., 2013c), rhizomes (Debnath et al., 2013) and marine algae (Kim et al., 2014) have been isolated and their anti-inflammatory effect studied by various mechanisms.

Mushrooms are nutritionally functional foods that have been an integral part of our diet for years. They have not just been consumed for their culinary importance because of their unique taste and flavour (Kalač, 2013), but also because of their potential therapeutic properties which dates back to over 2000 years ago and are recognized as effective to treat and prevent varieties of disorders (Lim et al., 2007; Moro et al., 2012; Silveira et al., 2014). Presently they are significantly consumed in western countries (Lindequist, Niedermeyer, \& Julich, 2005). The main commercial mushrooms are Agaricus bisporus L., Lentinus edodes 
(Berk.) Pegler and Pleurotus ostreatus (Jacq. ex Fr.) P. Kumm, known to be a vital source of proteins, carbohydrates, minerals and vitamins (Dore et al., 2007). Mushrooms (fruiting bodies, mycelia or their submerged fermentation broth) are rich in several bioactive compounds, either if wild, edible or cultivated species (Alves et al., 2013b). These bioactive metabolites include phenolic compounds, terpenoids, polysaccharides, lectins, steroids, glycoproteins and several lipid components ((Reis, Barros, Martins, \& Ferreira, 2012)). Several studies have been conducted to evidence the bioactive properties of mushroom extracts as well as of their secondary metabolites such as antioxidant (Ferreira, Barros, \& Abreu, 2009; Heleno, Martins, Queiroz, \& Ferreira, 2015; Puttaraju, Venkateshaiah, Dharmesh, Urs, \&Somasundaram, 2006), antitumor (Carocho \& Ferreira, 2013; Ferreira, Vaz, Vasconcelos, \& Martins, 2010; Moradali, Mostafavi, Ghods, \& Hedjaroude, 2007), antimicrobial (Alves et al., 2012, 2013a), immunomodulator (Borchers, Krishnamurthy, Keen, Meyers, \& Gershwin, 2008), antiatherogenic (Mori, Kobayashi, Tomita, Inatomi, \& Ikeda, 2008) hypoglycemic (Hu, Wang, Lien, Liaw, \& Lee, 2006) and anti-inflammatory (Moro et al., 2012; Tung et al., 2013; Han et al., 2013; Xu et al., 2013; Choi et al., 2014a; Taofiq et al., 2015) activities.

Most research studies conducted on the pharmacological potential of mushrooms are mainly focused on crude extracts. Nevertheless, it is also important to identify the bioactive compounds responsible for each one of the ascribed bioactivities. In this context, the antiinflammatory activity of several mushroom species has been reported as well as of their bioactive metabolites. It has been related with a reduction in the production of nitric oxide (NO) and other inflammatory mediators such as interleukins (IL 1 $\beta$, IL-6, IL-8), tumor necrosis factor (TNF- $\alpha$ ) and prostaglandin E2 (PGE2), causing reduction of inflammation (Jedinak, Dudhgaonkar, Wu, Simon, \& Sliva, 2011; Moro et al., 2012; Fangkrathok, Junlatat, 
\& Sripanidkulchai, 2013; Choi et al., 2014a; Lee et al., 2014; Gunawardena et al., 2014; Taofiq et al., 2015).

\section{Inflammatory mediators and cell signalling}

Inflammation is one of most important biological responses to remove harmful toxins or pathogens from the body (Jung et al., 2013). During inflammation, macrophages, monocytes and other inflammatory cells secrete excess inflammatory mediators, among them NO. Macrophages are the first line of defence against invading pathogens. They are large specialized cells that engulf and digest cellular debris, microbes, and cancer cells in a process called phagocytosis. They play important roles in non-specific host defence mechanism and help to initiate other defence mechanisms. Beyond stimulating the immune system, macrophages play a crucial role in the inflammatory response through the release of a variety of factors. Production of these mediators in inflammatory cells increases following exposure to immune stimulants including bacterial endotoxin lipopolysaccharide (LPS) or viral proteins (Hseu et al., 2005). This bacteria component initiates several signal transduction pathways that are central to the pathogenesis of inflammation (Jeong et al., 2010).

NO is a short-lived free radical and a signalling molecule produced from L-arginine by the inducible nitric oxide synthase (iNOS) enzyme (Hämäläinen, Nieminen, Vuorela, Heinonen, \& Moilanen, 2007; Castro et al., 2014). NO, known to induce vasodilation in the cardiovascular system through a $\mathrm{Ca}^{2+}$-dependent pathway, play an important function in the immune and nervous systems as well as in cell death (Hseu et al., 2005; Sharma, Al-Omran, \& Parvathy, 2007). It gives an anti-inflammatory effect under normal physiological conditions, being also involved in many pathological diseases in the body (Cirino, Distrutti, \& Wallace, 2006; Joo et al., 2014). 
Reactive oxygen species (ROS) production play an important role in the modulation of inflammation. Major ROS produced within the cell are superoxide anion $\left(\mathrm{O}_{2}{ }^{-}\right)$, hydrogen peroxide $\left(\mathrm{H}_{2} \mathrm{O}_{2}\right)$, peroxide anion $\left(\mathrm{O}_{2}{ }^{2-}\right)$, hydroxyl ion $\left(\mathrm{OH}^{-}\right)$and hydroxyl radical $(\mathrm{OH} \cdot)$. Nitric oxide is less reactive but has the ability to attack superoxide ion $\left(\mathrm{O}_{2}^{-}\right)$to form peroxynitrite $\mathrm{ONOO}^{-}$(Castro et al., 2014). This peroxynitrite and several oxidative products can accumulate in the cells causing several oxidative damages and increased cytotoxicity leading to tumor development, DNA damage and cell proliferation (Quang, Harinantenaina, Nishizawa, Hashimoto, Kohchi, Soma, \& Asakawa, 2006a; Fangkrathok, Junlatat, \& Sripanidkulchai, 2013). The inhibition of NO and other inflammatory mediators overproduction in cells may prevent the occurrence of inflammatory diseases and cancer (Cirino et al., 2006; Sharma, Al-Omran, \& Parvathy, 2007).

Another class of important pro-inflammatory mediator is the tumor necrosis factor- $\alpha$ (TNF- $\alpha)$ secreted by activated macrophages, T-lymphocytes, mast cells, natural killer cells, monocytes and other defence cells (Habtemariam, 2013). Tumor necrosis factor- $\alpha$ (TNF- $\alpha$ ) is one of the important pro-inflammatory mediators involved in the inflammatory process. When there is an immune stimulant, TNF- $\alpha$ attaches to some specific transmembrane receptors that tend to activate several signal transduction pathways responsible for production of more and more TNF- $\alpha$ to the site of infection (Bradley, 2008). As TNF- $\alpha$ continues to accumulate, it causes a wide range of human diseases, apoptosis, excess pain and cell damage. Regulation of the transcription factor NF- $\kappa \mathrm{B}$ is the key component of TNF- $\alpha$ regulation (Habtemariam, 2013). The inhibition of TNF- $\alpha$ in LPS activated THP-1 monocytic cells, or RAW 264.7 macrophage cells, is generally used as in vitro model for evaluating the anti- inflammatory effects of various materials including mushroom extracts (Wu, Lu, Lai, \& Ng, 2013a). Some of the studied mushrooms whose mechanism of action is the inhibition of TNF- $\alpha$ release are shown in Table 1. 
$\mathrm{NF}-\mathrm{\kappa B}$ is a transcription factor that regulates the expression of several pro-inflammatory cytokines and enzymes such as IL- $1 \beta$, TNF- $\alpha$, iNOS, and COX-2 that play vital roles in apoptosis, in the immune system, as well as in the inflammation (Hseu, Huang, \& Hsiang,

2010). When there is an immune stimulant such as lipopolysaccharide, viral proteins or cytokines, the NF- $\kappa \mathrm{B}$ becomes activated (Kim et al., 2003). Toll like receptors (TLRs) and tumor necrosis factor receptor (TNFr) localised in the macrophages membrane have the ability to detect these pathogen-associated microbial patterns (PAMPs) necessary for activation of several signalling cascade (Figure 1). After ligand binding, these receptors activate the myeloid differentiation protein 88 (MyD88) responsible for activation of mitogen activated protein kinase (MAPKs). This MAPKs further activate the IKK kinases (IKK $\alpha$, IKK $\beta$, IKK $\gamma$ ) leading to phosphorylation of IkB proteins complex (Hasnat, Pervin, Cha, Kim, \& Lim, 2015). Cytosolic IKB forms a complex with NF- $\kappa$ B and the IkB proteins becomes degraded allowing NF- $\mathrm{KB}$ to translocate to the nucleus where it triggers the transcription of several chemokine and cytokine genes involved in the innate and adaptive immune response (Kim et al., 2003). Some polyphenols have been known to inhibit specific steps in the pathway leading to NF- $\mathrm{BB}$ release (Ruiz \& Haller, 2006). These authors investigated the antiinflammatory mechanisms of flavonoids that were able to inhibit the phosphorylation of IkB preventing translocation of NF-kB to the nucleus. Hence, finding natural inhibitors of NF-kB for treatment and prevention of various inflammatory diseases have been the target of several scientists (Kim et al., 2003).

\section{NSAIDs and their mechanism of action}

The nonsteroidal anti-inflammatory drugs (NSAIDs) are a group of medications commonly administered to manage pain and inflammation (Moro et al., 2012). Most of them are available over the counter in the United States while the rest needs prescription (Meek, van 
de Laar, \& Vonkeman, 2010). Several side effects have been associated with frequent administration of NSAIDs particularly in the gastrointestinal (GI) tract where they cause bleeding, intestinal perforation and peptic ulcer (Dugowson \& Gnanashanmugam, 2006). Other less pronounce side effects include renal dysfunction, high blood pressure and cardiovascular toxicity (Elsayed, Hesham, Mohammad, \& Aziz, 2014). NSAIDs act by inhibiting the intracellular cyclo-oxygenase enzymes which has two isoforms (COX-1 and COX-2). Cyclooxygenase are enzymes involved in the process of inflammation (Noreen, Ringbom, Perera, Danielson, \& Bohlin, 1998). They catalyse the rate-limiting step in the biosynthesis of prostaglandins, prostacyclins, and thromboxanes from arachidonic acid (Zhang, Mills, \& Nair, 2003; Diyabalanage, Mulabagal, Mills, DeWitt, \& Nair, 2008; Stanikunaite, Khan, Trappe, \& Ross, 2009; Han, Oh, \& Park, 2011; Fangkrathok, Junlatat, \& Sripanidkulchai, 2013).

Prostaglandins (PG) are hormone-like chemicals in the body that perform "'housekeeping" functions required for normal physiological activities. They are structurally related and have regulatory roles as well as pathological implication (Silveira et al., 2014). Cyclooxygenase enzymes catalyzes the conversion of arachidonic acid to $\mathrm{PGH}_{2}$, which is converted to other prostanoid species including $\mathrm{PGD}_{2}, \mathrm{PGE}_{2}$, prostacyclin $\left(\mathrm{PGI}_{2}\right)$, and thromboxane $\left(\mathrm{TXA}_{2}\right)$ by the action of specific synthases (Figure 2) (Joo \& Sadikot, 2012). COX-1 is primarily involved in the regulation of homeostatic functions and is constitutively expressed in a wide variety of cells, promoting physiological functions, such as gastric mucosal protection, control of renal blood flow, hemostasis, autoimmune responses, lungs, central nervous system, cardiovascular system and reproductive functions (Grosser, Fries, \& Fitzgerald, 2006).

On the other hand, COX-2 is an inducible isoform of prostaglandin synthase in activated macrophages, fibroblasts, and endothelial cells that are responsible for inflammation. They 
are expressed significantly due to stimuli such as cytokines, endotoxins, viral proteins and growth factors. COX-2 originates inducing prostaglandins, which contributes to the development of the four cardinal signs of inflammation: pain, heat, redness and swelling, thus being considered as the main target for the anti-inflammatory action (Fitzgerald, 2004).

The search for selective inhibitors of COX-2 is considered important, on the basis of the theory that the side effects, such as gastric lesions, that occurred from inhibition of COX-1 activity, were observed with some non-selective nonsteroidal anti-inflammatory drugs (NSAIDs) (Supplementary material S1) such as dexamethasone, diclofenac and indomethacin (Lu et al., 2013). Until now, very few compounds of natural origin have been reported to possess COX-2 inhibitory effects. Yoshikawa et al. (2005) were the first to report the potential of lanostane triterpenoids and their glycosides as selective inhibitors of COX-2 enzyme.

Usually, NSAIDs inhibit both isoforms of the cyclooxygenase enzyme but the recently discovered selective COX-2 inhibitors (Supplementary material S2) are specific for the COX-2 isoform, thus exerting the anti-inflammatory property of COX-2 inhibition while theoretically evading the adverse effect associated with COX-1 isoform inhibition (Nowak, 2012). Considerable resources have thus been invested in the pharmaceutical industries for development and design of drugs that act through selective inhibition of COX-2 to control inflammation with improved tolerability, less adverse effects, and without affecting normal metabolic processes (Shukla, Bafna, Sundar, \& Thorat, 2014).

\section{Methodologies for anti-inflammatory activity screening}

\subsection{In vitro assays}

4.1.1. Nitric oxide assay. The Griess reaction is a simple technique that is widely used for quantification/detection of NO. It was discovered by Johann Peter Griess (1829-1888), a 
German organic chemist. The basic reaction involves reacting sulphaniliamide and N-(1naphthyl) ethylenediamine (NED) to form a stable azo compound. The absorbance of this compound at $540 \mathrm{~nm}$ is directly proportional to the nitrite concentration in the sample. Several in vitro measurement of NO production in LPS stimulated RAW 264.7 cells have been reported by several authors in the past, and this is one of the possible ways to screen various extracts and bioactive compounds with potential anti-inflammatory properties. RAW 264.7 cells are seeded in 96-well plates, they are then treated with different concentrations of the sample to be studied followed by stimulation with LPS. The cell culture supernatant is then transferred to a new plate followed by addition of sulphanilamide and NED solutions. The NO produced is determined by measuring the absorbance at $540 \mathrm{~nm}$. This assay is one of the most common and widely used for evaluation of anti-inflammatory activity as reported by different authors (Moro et al., 2012; Taofiq et al., 2015).

\subsubsection{Cytokine enzyme linked immunosorbent assay (ELISA). The enzyme linked} immunosorbent assay (ELISA) is used for the detection and quantification of proteins typically secreted or released from cells. This method is usually used for quantification of cytokines and other inflammatory mediators such as interleukin (IL-1 $\beta$, IL-6, IL-8) and tumour necrosis factor (TNF- $\alpha$ ), as reported in a number of publications (Jedinak, Dudhgaonkar, Wu, Simon, \& Sliva, 2011; Fangkrathok, Junlatat, \& Sripanidkulchai, 2013; Lee et al., 2014; Gunawardena et al., 2014). RAW 264.7 cells are usually plated in a 24-well plate in the culture medium, and then incubated with the sample to be screened at different concentrations. Cell culture supernatants are finally collected and assayed according to the instructions of the ELISA kit manufacturer (e.g., BD Pharmingen, San Diego CA, USA; DuoSet, R\&D Systems, UK; MAX ${ }^{\mathrm{TM}}$ Set (Deluxe); BioLegend, San Diego, CA, USA) to determine the amount of TNF- $\alpha$ and IL- 6 released from the cells. 


\subsection{3. $C O X-1$ and $C O X-2$ catalyzed prostaglandin biosynthesis assay}

The cyclooxygenase enzymes have been extensively used to study the anti-inflammatory potential of natural agents. This is not a very common method for anti-inflammatory activity assessment, but it has been reported in some publications (Noreen, Ringbom, Perera, Danielson, \& Bohlin, 1998; Zhang et al., 2003; Yoshikawa et al., 2005; Stanikunaite, Khan, Trappe, \& Ross, 2009). COX activity is usually determined based on the conversion of arachidonic acid to $\mathrm{PGE}_{2}$ and is expressed as a percentage of the control. RAW 264.7 cells are seeded in 96-well plates and incubated, being then stimulated with LPS to induce the production of COX-2 and other inflammatory mediators. Induced cells are treated with different concentrations of the samples. Arachidonic acid is added and the cells are further incubated. The amount of $\mathrm{PGE}_{2}$ released in the medium can be determined with $\mathrm{PGE}_{2}$ enzyme immunoassay kit (Cayman Chem. Co. Michigan, USA).

\subsection{In vivo assays}

A lot of studies have reported in vivo anti-inflammatory activity of natural products achieved by inducing inflammation in mouse and measuring the degree of swelling relative to a positive control. In these animal models there is capillary dilation, increase blood vessel permeability, and edema similar to the ones associated with human acute inflammation (Wang et al., 2013a). The carrageenan-induced hind paw edema model has been used in a lot of research studies (Jose, Ajith, \& Jananrdhanan, 2004; Deng et al., 2013; Lee et al., 2014). The methodology involves treating animals with extract at different concentration and also a control group with indomethacin, dexamethasone or any other non-steroidal antiinflammatory drug. This is followed by injection of hind paw with carrageenan in saline solution and by measuring the paw volume increment immediately and at different time 
intervals (Lu et al., 2008). The degree of swelling induced by the injection is evaluated and the result compared with the control. Inflammation can also be induced by topical application of xylene in the ear of the mouse. After few minutes, the difference in swelling (Lu et al., 2008 ) is estimated. Other in vivo anti-inflammatory assay induce inflammation, either by the croton oil-induced ear edema test (Kim et al., 2004; Won \& Park, 2005; Dore et al., 2007) or by TPA, 12-O-tetradecanoylphorbol-13-acetate induced inflammation in mice, and sacrificed by cervical dislocation, to take punch biopsies to weight (Kamo, Asanoma, Shibata, \& Hirota, 2003; Dore et al., 2007; Liu et al., 2007).

\section{Mushroom metabolites with reported anti-inflammatory activity}

\subsection{The anti-inflammatory potential of mushroom extracts}

Numerous investigations have suggested that several mushroom species can exhibit antiinflammatory potential based on their ability to reduce the production of inflammatory mediators (Kim et al., 2003; Padilha et al., 2009; Wen et al., 2011; Elsayed, Hesham, Mohammad, \& Aziz, 2014 Taofiq et al., 2015). Their crude extracts (Table 1) have been described to display activity, and attention is now being focused on efforts to discover bioactive compounds capable to suppress the production of inflammatory mediators through gene expression downregulation of different types of inflammatory mediators (Kim et al., 2006, Fangkrathok, Junlatat, \& Sripanidkulchai, 2013). Previous research studies have been carried out on several mushroom species, mainly in methanolic (Kim et al., 2003; Wen et al., 2011; Moro et al., 2012) and ethanolic (Won \& Park, 2005; Kim et al., 2006; Ruthes et al., 2013b; Taofiq et al., 2015) extracts. Most studies have shown that these extracts display antiinflammatory activity, but it is also crucial to identify the metabolites responsible for this bioactivity. 
Different compounds have been isolated from mushrooms and implicated as responsible for the anti-inflammatory activity, e.g. polysaccharides (Dore, et al., 2007; Lu, et al., 2008; Lavi, Levinson, Peri, Hadar, \& Schwartz, 2010; Adebayo, Oloke, Majolagbe, Ajani, \& Bora, 2012; Ruthes, et al., 2013a, 2013b, 2013c; Chang, Lur, Lu, \& Cheng, 2013; Castro et al., 2014; Silveira et al., 2014; Silveira et al., 2015), terpenes (Kamo, Asanoma, Shibata, \& Hirota, 2003; Yoshikawa et al., 2005; Dudhgaonkar, Thyagarajan, \& Sliva, 2009; Han et al., 2013; Ma, Chen, Dong, \& Lu, 2013; Tung et al., 2013; Xu, Yan, Bi, Han, Chen, \& Wu, 2013; Choi, et al., 2014a), phenolic compounds (Quang, Harinantenaina, Nishizawa, Hashimoto, Kohchi, Soma, \& Asakawa, 2006a; Quang et al., 2006b Kohno et al., 2008; Stanikunaite, Khan, Trappe, \& Ross, 2009; Hsieh et al., 2010; Lee, \& Huang et al., 2011b; Chen et al., 2013; Taofiq et al., 2015), sterols (Huang, et al., 2010; Ma, Chen, Dong, \& Lu, 2013; Li, Zhou, Lee, Shim, Kim, \& Kim, 2014b), fatty acids (Zhang, Mills, \& Nair, 2003; Han \& Cui, 2012), polysaccharide - protein complexes (Chen, Gonzalez de Mejia, \& Wu, 2011; Zhou, Chen, Ding, Yao, \& Gao, 2014) and other bioactive metabolites (Chien, Chen, Kuo, Tsai, Lin, \& Kuo, 2008; Jeong et al., 2010). The anti-inflammatory properties of mushrooms have interested many scientists and motivated the study of several species (Table 1).

Antrodia camphorata (M.Zang \& C.H.Su) Sheng H.Wu, Ryvarden \& T.T.Chang also known as "Taiwanofungus camphoratus" is a well-known medicinal mushroom with a lot of pharmacological potential. It has been reported to have antioxidant, hepatoprotective, antiinflammatory and immunomodulatory properties (Geethangili \& Tzeng, 2011). Hseu, Huang, \& Hsiang (2010) reported the anti-inflammatory effect of fermented culture broth of $A$. camphorata by measuring the level of pro-inflammatory cytokine IL-1 $\beta$ and TNF- $\alpha$ expression in different organs using ELISA kits. The extract was found to inhibit the LPSinduced production of cytokines and also to suppress LPS-induced NF-kB activation in transgenic mice. The same researchers also studied fermentation culture of $A$. camphorata 
and examined its effect in LPS stimulated RAW 264.7 cells for NO, PGE2, iNOS and COX-2 protein expression. The results indicate that $A$. camphorata inhibit the production of TNF- $\alpha$ and IL-1 $\beta$, NO and PGE2, as well as iNOS and COX-2 expression by blocking activation of $\mathrm{NF}-\kappa \mathrm{B}$ transcription factor.

Gunawardena et al. (2014) studied the anti-inflammatory potential of five commercial mushroom species (Agaricus bisporus, Agaricus bisporus Portobello J.E.Lange, Flammulina velutipes (Curtis) Singer, Lentinus edodes, and Pleurotus ostreatus in LPS activated RAW 264.7 macrophages cells for NO production and also detected TNF- $\alpha$ level using ELISA kit. Three mushroom species showed the highest activity with the result expressed in terms of $\mathrm{IC}_{50}$ for NO production and TNF- $\alpha$ release respectively: Pleurotus ostreatus $(0.077 \mathrm{mg} / \mathrm{mL}$ and $0.035 \mathrm{mg} / \mathrm{mL}$ ), Lentinus edodes $0.027 \mathrm{mg} / \mathrm{mL}$ and $0.047 \mathrm{mg} / \mathrm{mL}$ ) and Flammulina velutipes $0.024 \mathrm{mg} / \mathrm{mL}$ and $0.099 \mathrm{mg} / \mathrm{mL}$ ). Gunawardena et al. (2014) also demonstrated the anti-inflammatory activity of extracts prepared from mushrooms after undergoing some food processing procedures. The results showed reduced activity compared to fresh samples, which implies that anti-inflammatory compounds present in these mushrooms were degraded, e.g due to suseptibility to heating.

Ganoderma lucidum (Curtis) P. Karst., is a medicianal mushroom that has been used to reduce allergies, inflammation, has anti-tumor and anti-aging potential, as well as health promoting effects. Ethanolic extract of Ganoderma lucidum was studied for its antiinflammatory potential by stimulating murine BV2 cell line with LPS, and the amount of NO, PGE2 and Cytokine( IL-1 $\beta$ and TNF- $\alpha$ ) in culture supernatants quantified as reported by Yoon et al. (2013). Treatment of cell line with extract up to $1 \mu \mathrm{g} / \mathrm{ml}$ significantly repressed the production of NO due to the inhibition of iNOS mRNA protein expression. The amount of cytokine release was measured by ELISA and a significant reduction in the level of cytokines after treatment with extract was observed. The anti-inflammatory ativity was 
further associated to the inhibition of the NF- $\mathrm{KB}$ signaling pathway by the ethanolic extract. Methanolic extract of Ganoderma lucidum was also evaluated by Chu et al. (2015). RAW264.7 monocytic cells were stimulated with LPS and treated with extract at different concentrations. From the result, $100 \mu \mathrm{g} / \mathrm{ml}$ of extract significantly inhibited NO production in the culture medium up to $85 \%$.

Moro et al. (2012) analysed six mushroom species from Spain (Boletus edulis Bull., Cantharellus cibarius Fr., Craterellus cornucopioides (L.) Pers., Lactarius deliciosus, (L. ex Fr.) S.F.Gray Agaricus bisporus and Pleurotus ostreatus) in what concerns the antiinflammatory activity of their methanolic extracts through NO production in LPS stimulated RAW 264.7 cells. At a concentration of $0.5 \mathrm{mg} / \mathrm{mL}$, Agaricus bisporus, Cratarellus cornucopioides, Cantharellus cibarius and Lactarius deliciosus showed 35\%, 65\%, 80\% and $40 \%$ of NO production inhibition, respectively. The release of TNF- $\alpha$ production was estimated by ELISA kits, but methanolic extracts showed no reduction of TNF- $\alpha$ production in the macrophages.

Taofiq et al. (2015) studied the anti-inflammatory activity of ethanolic extracts of ten wild and four cultivated mushroom species from the Northeast of Portugal. RAW 264.7 macrophage cells were stimulated with LPS and then the amount of NO production was quantified using the griess reagent assay. The $\mathrm{IC}_{50}$ value responsible for $50 \%$ inhibition of NO production estimated and among the studied species was as follows: Pleurotus ostreatus presented the best results $(96 \mu \mathrm{g} / \mathrm{mL})$, followed by Macrolepiota procera (Scop.) Singer (162 $\mu \mathrm{g} / \mathrm{mL})$, Boletus impolitus Fr. (166 $\mu \mathrm{g} / \mathrm{mL})$ and Agaricus bisporus $(190 \mu \mathrm{g} / \mathrm{mL})$. In oposition, ethanolic extracts of Agaricus bisporus Portobello, Boletus edulis and Boletus flagrans Vittad., did not display activity.

Kim et al. (2004) studied the Phellinus linteus (Berk. \& M. A. Curtis) Teng, an orange colour mushroom used in China, Japan and other oriental countries for health maintenance. The 
ethanolic extracts obtained from the fresh fruiting bodies of $P$. linteus were investigated in vivo for anti-inflammatory potential based on their ability to inhibit inflammation (edema) induced by croton oil in mice. Topical aplication of extract at $1.0 \mathrm{mg}$ per ear gave $41.5 \%$ edema inhibition, when compared with indomethacin, which gave rise to a quite higher inhibition (71.7\%). Kim et al. (2006) also demonstrated the anti-inflammatory activity of the ethanolic extracts of $P$. linteus in LPS-stimulated RAW264.7 macrophages. The extracts at different concentrations dependently reduced iNOS promoter activity and NO production; at $0.5 \mathrm{mg} / \mathrm{mL}$, the extract had $60 \%$ of NO production inhibition.

Cordyceps, a genus of mushroom known to grow on insects and have been reported to strengthen the immune system (Won \& Park, 2005). Rao, Fang, Wu, \& Tzeng (2007), studied anti-inflammatory activity using methanolic extracts from the fruiting body of Cordyceps sinensis (Berk.) Sacc., and by stimulating macrophages cells with LPS and NO production later quantified. The amount of TNF- $\alpha$ level and IL-12 were quantified by the ELISA test. From the results, $100 \mu \mathrm{g} / \mathrm{mL}$ of $C$. sinensis extract inhibited NO production by $70 \%$. Han, Oh, \& Park (2011) also studied the anti-inflammatory effect of hot water extract of Cordyceps militaris (L.) Fr. in vivo by inducing inflammation in mice. The extracts were known to inhibit inflammation as well as iNOS and TNF-mRNA expression in colon tissue of DSS-induced colitis and in LPS-stimulated RAW264.7 cells. Kim et al. (2003) also described the anti-inflammatory activity of another Cordyceps specie. Methanolic extracts of C. pruinosa (L.) Fr. were tested in vitro for inhibition of pro-inflammatory cytokines production by using ELISA kit as well as NO production in LPS stimulated RAW264.7 macrophages. The extracts were known to suppress gene expression of IL- $1 \beta$, TNF- $\alpha$, inducible nitric oxide synthase, and cyclooxygenase- 2 enzyme. This is due to the inhibition of nuclear transcription factor NF- $\mathrm{KB}$ activation. 


\subsection{Polysaccharides}

Mushrooms have been known as valuable sources of bioactive carbohydrates, namely polysaccharides which represent the main group with various health promoting properties (Villares, 2013). They include several different $\beta$-glucans (Supplementary material S3), fucomannogalactans, xylomannans and mannogalactans, known to play different biological roles such as the ones of antioxidation, anti-inflammatory, antitumour, antimicrobial, antiaging, neuroprotective and immunomodulatory (Li et al., 2013).

Studies on the anti-inflammatory properties of carbohydrates have led to positive results as shown in Table 2. Several types of polysaccharides have been obtained from mushroom dry fruiting bodies or mycelia and tested for anti-inflammatory activity either in vivo (Lu et al., 2008; Ruthes et al., 2013c; Silveira et al., 2015), following a typical model similar to human acute inflammation, or in vitro for inhibition of cytokine or NO production (Dore et al., 2007; Chang et al., 2013; Castro et al., 2014).

Several pharmacological properties have been reported on the extracts and bioactive compounds isolated from Cordyceps militaris, namely the anti-inflammatory activity (Rao, et al., 2010). D-Glucose, D-mannitol and 3,4-O-isopropylidene-D-mannitol were isolated from its fruiting body and the anti-inflammatory potential evaluated in mouse peritoneal macrophages regarding the inhibition of NO production and cytokine release. Among the three cited compounds, D-Glucose showed the highest $\mathrm{NO}$ inhibition potential with an $\mathrm{IC}_{50}$ value of $11.3 \mu \mathrm{g} / \mathrm{mL}$, followed by D-mannitol $(14.2 \mu \mathrm{g} / \mathrm{mL})$ and 3, 4-O-isopropylidene-Dmannitol (17.2 $\mu \mathrm{g} / \mathrm{mL})$. They also inhibit significantly cytokines (TNF- $\alpha$ and IL-12) production, indicating that they may be useful compounds for the design of antiinflammatory agents.

Mushroom polysaccharides vary in structure and sometimes they exhibit different biological effects. Silveira et al. (2014) isolated a $(1 \rightarrow 3)-\beta$-D-glucan from the fruiting body of 
Pleurotus sajor-caju (Fr.) Singer and tested its anti-inflammatory effect in a monocytic cell line THP-1 after LPS induction, for inhibition of pro-inflammatory genes production. Monocyte cells showed a significant decrease in TNF- $\alpha$ expression (61.8\% inhibition) while IL-1 $\beta$ and COX-2 mRNAs were also significantly inhibited (37.0\% and 63.6\%, respectively). Silveira et al. (2015) isolated a mannogalactan from $P$. sajor-caju by submerged fermentation. The purified polysaccharide was chemically characterized and its antiinflammatory potential evaluated in vivo for reduction of carrageenan-induced paw edema in mice. The group treated with purified mannogalactan was able to reduce edema after 5-6h of exposure to $1 \%$ carrageenan, with $69-71 \%$ edema reduction observed, and was quite as effective as dexamethasone used as control. Therefore, mushroom polysaccharides have shown to be lead compounds for development of anti-inflammatory agents.

Agaricus bisporus is one of the most commonly consumed mushrooms in the world. Ruthes et al. (2013b) isolated and purified a fucogalactan from its dried fruiting bodies, and its antiinflammatory effect was evaluated in vivo by formalin-induced pain in mice and detection of iNOS and COX-2 protein expression. Fucogalactan significantly decreased both iNOS and COX-2 expression by $53 \%$ and $54 \%$, respectively, in relation to dexametasone used as control, which also affected both iNOS and COX-2 expression by $74.5 \%$ and $71.4 \%$, respectively. The results reported showed significant inhibition of inflammatory pain and strongly confirm the anti-inflammatory potential of fucogalactan.

Xu, Yasuda, Nakamura-Tsuruta, Mizuno, \& Ashida (2012) isolated a $\beta$-glucan (lentinan) from the fruiting bodies of Lentinus edodes and investigated this effects on NO and TNF- $\alpha$ production in LPS stimulated murine RAW 264.7 macrophages. Lentinan, at a concentration of $200 \mu \mathrm{g} / \mathrm{mL}$, was found to significantly inhibit NO production (70\%) and was dosedependent. Also the amount of TNF- $\alpha$ released from RAW 264.7 cells was quantified and found to be suppressed by $75 \%$ at $200 \mu \mathrm{g} / \mathrm{mL}$. Furthermore, the protein expression of iNOS 
and the gene expression of iNOS mRNA and TNF- $\alpha$ mRNA were suppressed by lentinan suggesting its usefulness as an anti-inflammatory agent. Mizuno, Nishitani, Hashimoto, \& Kanazawa (2009) also reported the anti-inflammatory effect of this compound, which was analysed for inhibition of TNF- $\alpha$ production as well as IL-8 expression. At $500 \mu \mathrm{g} / \mathrm{mL}$, it was able to down regulate IL-8 mRNA expression in RAW 264.7 stimulated with LPS.

\subsection{Terpeneoids}

Terpenoids are organic compounds found in plants, animals and macrofungi. They are empirically regarded as built up from isoprene, a hydrocarbon consisting of five carbon atoms with molecular formula $\left(\mathrm{C}_{5} \mathrm{H}_{6}\right) \mathrm{n}$ as repeating unit (El Enshasy \& Hatti-Kau, 2013). The terpene compounds are named based on the number of isoprene units, for example, monoterpenes (10 carbons), sesquiterpenes (15 carbons), diterpenes (20 carbons), sesterterpenes (25 carbons), triterpenes (30 carbons), and tetraterpenes (40 carbons). Among the large number of terpenes, triterpenoids are exclusively found in certain macrofungi, mainly Basidiomycetes, and are recognized for their biological activity and medicinal purposes. Several researchers have isolated some of these terpenoid coumpounds from mushrooms and, among them; the titerpenoids are the most reported (Table 3). Their ability to induce significant decrease in NO production as well as other cytokines was evaluated. Common examples include ganoderol, ianostane, lucidadiol and lucidone (Supplementary material S4) isolated, from the fruiting body of Ganoderma lucidum (Akihisa et al., 2007; Dudhgaonkar, Thyagarajan, \& Sliva, 2009; Choi et al., 2014a).

Ganoderma lucidum has been used in the past to promote health and longevity in Asia. Choi et al. (2014a) isolated 12 triterpenes from its fruiting body and the anti-inflammatory activity evaluated in LPS induced RAW 264.7 cells. Seven triterpenes; butyl lucidenate E2 (GT-1), butyl lucidenate D2 (GT-2), butyl lucidenate P (GT-3), butyl lucidenate Q (GT-4), 
Ganoderiol F (GT-5), methyl ganodenate J (GT-7) and butyl lucidenate N (GT-12), out of the studied twelve triterpenes, showed significant decrease in NO production. $20 \mu \mathrm{M}$ of GT-2 showed up to $70 \%$ inhibition of $\mathrm{NO}$ production relative to the control. Dudhgaonkar, Thyagarajan, \& Sliva (2009) also studied triterpene rich ethanolic extracts from G. lucidum in LPS stimulated RAW 264.7 macrophage cells. The extract at $10-50 \mu \mathrm{g} / \mathrm{mL}$ suppressed TNF$\alpha$ production in RAW 264.7 cells $\left(\mathrm{IC}_{50} 15.1 \mu \mathrm{g} / \mathrm{mL}\right.$ ), reduced IL-6 production $\left(\mathrm{IC}_{50} 14.4\right.$ $\mu \mathrm{g} / \mathrm{mL}$ ) and decreased the secretion of $\mathrm{PGE}_{2}$ and $\mathrm{NO}$ in a dose-dependent manner with $\mathrm{IC}_{50}$ values of $28.2 \mu \mathrm{g} / \mathrm{ml}$ and $11.4 \mu \mathrm{g} / \mathrm{mL}$, respectively.

Cyathus africanus H. J. Brodie, also known as "bird nest fungi", usually grows on animal dungs, woody debris and soil rich in humus. Han et al. (2013) isolated diterpenes from its fruiting body and the anti-inflammatory activity was evaluated regarding NO production in LPS induced macrophages. Five diterpenes showed potent NO inhibition with $\mathrm{IC}_{50}$ values of $2.57,1.45,12.06,10.73$, and $9.45 \mu \mathrm{M}$, compared to hydrocortisone used as the control with $\mathrm{IC}_{50}$ value of $53.78 \mu \mathrm{M}$.

Piptoporus betulinus (Bull. ex Fr.) P. Karst., also known as "bracket fungi" is an edible mushroom that is geographically restricted to the cold climates. Kamo, Asanoma, Shibata, \& Hirota, (2003) isolated six lanostane-type triterpene acids from its fruiting bodies collected in Japan. The anti-inflammatory activity was tested in vivo by inducing inflammation (edema) in mouse ear using TPA (12-O-tetradecanoylphorbol-13-acetate). The isolated compounds suppressed the TPA-induced edema up to $49-86 \%$ at $400 \mathrm{nmol} / \mathrm{ear}$ application. Some of the isolated compounds (polyporenic acids A, three derivatives of polyporenic acid A and a novel compound (+)-12 $\alpha$, 28-dihydroxy-3 $\alpha$-(3'-hydroxy-3'-methylglutaryloxy)-24-methyllanosta-8, 24(31)-dien-26-oic acid) have displayed higher activity than indomethacin used as positive control. 


\subsection{Polyphenols}

Phenolic compounds are characterized by at least one aromatic ring (C6) and one or more hydroxyl groups (Michalak, 2006). These molecules, including phenolic acids, are a group of secondary metabolites from fungi and plants, secreted for protection against UV light, insects, viruses and bacteria (Heleno, Martins, Queiroz, \& Ferreira, 2015). Mushrooms are known to produce an amazing diversity of secondary metabolites. Phenolic compounds are one of the most important groups of these metabolites, being attractive because of their multifunctional properties. These compounds provide protection against several chronic diseases such as cancer, brain malfunction and several cardiovascular illnesses. Different research studies have reported the bioactive potential of phenolic acids, but only few studied the bioactive properties of their synthesised metabolites (Heleno, Martins, Queiroz, \& Ferreira, 2015).

Several classes of phenolic compounds (Supplementary material S5) and some of their derivatives, present in mushroom extracts, have been evaluated and known to have antiinflammatory activity (Table 4).

Antrodia camphorata, very common in Taiwan, has enormous amount of bioactive compounds with reported pharmacological potential (Geethangili \& Tzeng, 2011). Several benzenoids and benzene derivatives have been isolated from A. camphorata and tested for anti-inflammatory activity. Chen et al. (2013) isolated three new benzenoids from $A$. camphorata and evaluated their anti-inflammatory activity in LPS induced RAW 264.7 cells regarding the inhibition of $\mathrm{NO}$ production. The $\mathrm{IC}_{50}$ values of the three compounds (3isopropenyl-2-methoxy-6-methyl-4,5-methylenedioxyphenol (1), 4,4'-dihydroxy-3,3'dimethoxy-2,2'- dimethyl-5,6,5',6'-bimethylenedioxybiphenyl (2), 2,3-methylenedioxy-4methoxy-5-methylphenol (3) ) were 1.8, 18.8 and $0.8 \mu \mathrm{g} / \mathrm{mL}$. Other phenolic derivatives from A. camphorata are antrocamphin and benzocamphorin that have attracted considerable 
attention recently because of their significant anti-inflammatory activity. Liao, Kuo, Liang, Shen, \& Wu (2012) isolated benzocamphorin F from the fruiting body of Taiwanofungus camphoratus and evaluated its anti-inflammatory activity in murine microglial cells (BV2). Inhibition of $\mathrm{NO}$ production was expressed in terms of $\mathrm{IC}_{50}$ and the compound reached a value of $8.6 \mu \mathrm{M}$ compared to L-NAME, a non-specific NOS inhibitor, with an $\mathrm{IC}_{50}$ of 12.0 $\mu \mathrm{M}$.

Albatrellus caeruleoporus (Peck) Pouzar is an edible mushroom that grows on woody debris as well as on the ground, common in North America. Quang et al., (2006b) chemically characterized its methanolic extracts in terms of phenolic acids and evaluated their antiinflammatory potential in LPS induced RAW 264.7 cells regarding NO production. All four identified grifolin derivatives showed a significant reduction in $\mathrm{NO}$ production with $\mathrm{IC}_{50}$ values of $23.4,22.9,29.0$, and $23.3 \mu \mathrm{M}$ compared to $88.4 \mu \mathrm{M}$ of NG-methyl-L-arginine (LNMMA), a potent inhibitor of NO production used as control.

Elaphomyces granulatus Fr. is an inedible mushroom known as "false truffle" in the United Kingdom and widely distributed in Europe and North America. Stanikunaite, Khan, Trappe, \& Ross (2009) studied the ethanolic extracts of E. granulatus and isolated syringaldehyde and syringic acid from its fruiting body. Extracts and phenolic acids were evaluated for their anti-inflammatory activity in RAW 264.7 macrophages cells by the COX-1- and COX-2catalyzed prostaglandin biosynthesis assay. The extracts caused a $68 \%$ inhibition of COX-2 activity at $50 \mu \mathrm{g} / \mathrm{mL}$. Syringaldehyde and syringic acid moderately inhibited COX-2 activity with $\mathrm{IC}_{50}$ values of $3.5 \mu \mathrm{g} / \mathrm{mL}$ and $0.4 \mu \mathrm{g} / \mathrm{mL}$, respectively. NS-398, a specific inhibitor of COX-2, was used as a positive control and had $\mathrm{IC}_{50} 0.2 \mu \mathrm{g} / \mathrm{mL}$.

Phellinus linteus is a medicinal mushroom used for centuries in oriental countries to prevent several diseases (Kim, Song, Kim, Kim, Lim, \& Park, 2004). Several phenolic compounds have been isolated from the fruiting body and mycelia of $P$. linteus; among them are caffeic 
acid, hispolon, hispidin, hydroxybenzaldehyde and inotilone (Huang, Huang, \& Deng, 2012a). Lin et al. (2014b) isolated hispolon from fermentation broth of P. linteus and its antiinflammatory activity was evaluated in LPS induced RAW 264.7 cells regarding inhibition of NO production. Hispolon at $10 \mathrm{mg} / \mathrm{mL}$ inhibited NO production by $72.1 \%$ and suppressed the expression levels of iNOS. Hence this compound has useful therapeutic potential, additional research studies need to be conducted in order to understand its mechanism of action. Huang, Huang, \& Deng (2012a) isolated inotilone, another important phenolic compound with reported anti-inflammatory potential, from the fruiting body of $P$. linteus and tested the antiinflammatory effects in vivo in carrageenan induced hind mouse paw edema model as well as in vitro for inhibition of $\mathrm{NO}$ production and iNOS expression. Carr-induced mouse paw edema volume was significantly decreased to $56.2 \%$, NO production was inhibited up to 26.2-59.7\%, TNF- $\alpha$ release was inhibited up to $10.6-40.3 \%$ while iNOS expression was significantly inhibited in a dose-dependent manner. Inhibition of NF-kB and MAPK activation were also observed and are the major mechanisms responsible for cytokine and other inflammatory mediator release.

\subsection{Steroids}

Steroids are organic compounds with three hexagonal and one pentagonal carbon rings arranged in specific configuration with several functional groups found in plants, animals and fungi (Streck, 2009). Ergosterol is a precussor of vitamin D found in mushrooms membrane and known to vary among species depending on the physiological state of the mushroom (Chiocchio \& Matković, 2011). Steroids in general have been reported to play several biological functions such as anti-tumor, anti-oxidant, immune function as well as prevention of common diseases (Phillips et al., 2011). 
Steroids (Table 5) such as trametenolic acid, ergosterol peroxide, and ergosterol (Supplementary material S6) have been isolated from mushrooms and were reported to present anti-inflammatory activity.

Inonotus obliquus (Ach. ex Pers.) Pilát, also known as "chaga mushroom" is a medicinal mushroom used in Russia and other North-European countries. Among others, anti-tumour and immunomodulatory properties were reported (Fan, Ding, Ai, \& Deng, 2012). Ma, Chen, Dong, \& Lu (2013) isolated six main constituents from its fruiting body and their antiinflammatory activity was evaluated for NO production in RAW 264.7 cell lines. Among the isolated compounds, ergosterol peroxide and trametenolic acid had the highest antiinflammatory potential and significantly inhibited NO production by $36.88 \%$ and $50.04 \%$,

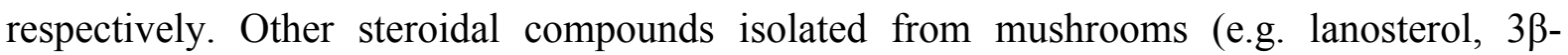
hydroxy-8, 24-dien-21-al, ergosterol and inotodiol) had relatively low percentages of NO production inhibition.

Antrodia camphorata is a medicinal mushroom with reported anti-inflammatory activity (Hseu et al., 2005; Liu et al., 2007; Hsieh et al., 2010; Hseu, Huang, \& Hsiang, 2010; Lee et al., 2011b; Liao, Kuo, Liang, Shen, \& Wu, 2012; Deng et al., 2013; Chen et al., 2013). Ergostatrien-3 $\beta$-ol was isolated from the fruiting body of $A$. camphorata by submerged fermentation (Huang et al., 2010). The anti-inflammatory activity was evaluated in vivo for reduction of NO production as well as for serum levels of TNF- $\alpha$ using a commercial ELISA kit. This compound significantly inhibited NO and TNF- $\alpha$ levels after Carrageenan injection and inhibited iNOS and COX-2 protein expression in the animal model. These results suggest that the compound may be useful to develop new anti-inflammatory agents, and the mechanism of action may be related to inhibition of iNOS expression.

Pleurotus species are among the most cultivated edible muhrooms in the world with high nutritional value and reported medicinal properties. Several Pleurotus species have been 
studied for the anti-inflammatory effect of their extracts as well as their bioactive metabolites; examples are Pleurotus citrinopileatus Singer; Pleurotus eryngii (DC.) Quél; Pleurotus florida Singer; Pleurotus ostreatoroseus Singer; Pleurotus ostreatus (Jacq. ex Fr.) P. Kumm.; Pleurotus pulmonarius (Fr.) Quél; Pleurotus sajor-caju (Fr.) Singer and Pleurotus tuber-regium (Rumph. ex Fr.) Singer. Liu et al. (2014) reported the anti-inflammatory activity of ethanolic mycelia extract of Pleurotus tuber-regium produced by submerged fermetation broth in LPS induced murine macrophage cell line RAW 264.7. Two compounds, cerevisterol (CE) and ergosta-4, 6, 8(14), 22-tetraen-3-one, were isolated, characterised and their anti-inflammatory activity evaluated. From the result, both compounds at $10 \mu \mathrm{M}$ inhibited NO production in a dose dependent manner, very similar to control. They also significantly inhibited TNF- $\alpha$, IL-6, and PGE2 release from the cell culture supernatant. The anti-inflammatory activity was reported to be due to down regulation of iNOS and COX-2 mRNA protein expression.

\subsection{Other metabolites}

Beside the major compounds with reported anti-inflammatory activity, other bioactive metabolites (Supplementary material S7) such as fatty acids, succinic and maleic derivatives, adenosine, cordycepin and glycopeptides have been studied (Table 6) and known to inhibit the production of inflammatory mediators as well as to suppress the induced inflammation in vivo.

Fomes fomentarius is an inedible mushroom specie common in Europe, Asia and North America, known for its large fruiting body and decomposing property. Its fruiting body was extracted with methanol and methyl 9-oxo-(10E, 12E)-octadecadienoate isolated (Choe, Yi, Lee, Seo, Yun, \& Lee, 2015). The anti-inflammatory activity was evaluated in peritoneal macrophages for NO, PGE2 production, TNF- $\alpha$ and IL-6 release. At $20 \mu \mathrm{g} / \mathrm{mL}$, the 
compound significantly inhibited NO and PGE2 by $65 \%$ and $50 \%$, respectively, while TNF- $\alpha$ and IL-6 levels were inhibited up to $35 \%$ and $13 \%$, respectively. Finally, the mechanism of action of the compound was found to be due to inhibition of iNOS and COX-2 protein expression and also due to a slight inhibition of phosphorylation of ERK1/2 kinase.

Polysaccharide protein complexes obtained from mushroom have been known to play several biological functions such as immunomodulatory, antitumour and antioxidant (Wu, Chen, \& Siu, 2014). The anti-inflammatory activity of several glycoproteins have been reported by some authors (Chen, De Mejia, \& Wu, 2011; Lau, Abdullah, Aminudin, Lee, \& Tan, 2015). The anti-inflammatory activity of a glycopeptide from Ganoderma capense (Lloyd) Teng was evaluated in RAW264.7 cells for NO production and for iNOS enzyme activity (Zhou, Chen, Ding, Yao, \& Gao, 2014). It was found that LPS-induced NO production and iNOS expression were significantly inhibited in a dose-dependent manner.

Many studies have reported the fatty acids composition of commercial and wild mushroom species (Barros, Baptista, Correia, Casal, Oliveira, \& Ferreira, 2007). Agaricoglycerides is a fungal secondary metabolite made up of esters of chlorinated 4-hydroxy benzoic acid and glycerol. Han \& Cui (2012) isolated this compound from fermented broth of Grifola frondosa (Dicks.) Gray and evaluated its anti-inflammatory activity by measuring in vivo levels of COX-2, ICAM-1, and iNOS. TNF- $\alpha$ and IL-1 $\beta$ levels were also quantified using an ELISA kit. Exposure to the compound at $500 \mathrm{mg} / \mathrm{kg}$ significantly decreased the level of IL-1 $\beta$ and TNF- $\alpha$, and suppressed iNOS expression in LPS induced cells.

\subsection{Commercial and synthesised compounds}

Researchers have attempted to synthesize compounds with improved properties as drug candidates with the potential to inhibit production of $\mathrm{NO}$ and other inflammatory mediators 
such as interleukins (IL 1 $\beta$, IL-6, IL-8), TNF- $\alpha$ and PGE2. Some synthesised and commercial compounds with positive anti-inflammatory potential have been reported (Table 7).

Taofiq et al. (2015) studied the anti-inflammatory activity of commercial phenolic acids ( $p$ hydroxybenzoic and p-coumaric acids) and cinnamic acid, and of their synthesised metabolites (glucuronated $p$-coumaric acid, methylated $p$-coumaric acid, glucuronated cinnamic acid, methylated cinnamic acid, methylated $p$-hydroxybenzoic acid, glucuronated $p$ hydroxybenzoic acid) from parental phenolic acids (Heleno, Ferreira, Calhelha, Esteves, \& Queiroz, 2014). All compounds were then tested for their potential to inhibit NO production in LPS stimulated RAW 264.7 cells. Cinnamic acid had the highest activity $\left(\mathrm{IC}_{50}\right.$ value 182 $\mu \mathrm{M})$, followed by $p$-hydroxybenzoic $(239 \mu \mathrm{M})$ and $p$-coumaric $(442 \mu \mathrm{M})$ acids, in comparison with dexamethasone $(40 \mu \mathrm{M})$ used as control. Among the synthesized metabolites, CoA-GP (glucuronated derivative of $p$-coumaric acid) and CoA-M1 (methylated derivative with the methoxy group at the para position) presented strong anti-inflammatory activity with $\mathrm{IC}_{50}$ values of $58 \mu \mathrm{M}$ and $35 \mu \mathrm{M}$, respectively.

Several publications have reported the medicinal properties of Cordyceps mushroom, including the anti-inflammatory activity (Kim et al., 2003; Won \& Park, 2005; Rao, Fang, \& Tzeng, 2007; Rao, Fang, Wu, \& Tzeng, 2010; Han, Oh, \& Park, 2011). This mushroom contains a lot of bioactive compounds and "Cordycepin" an adenosine analogue is the most important one. Jeong et al. (2010) studied the anti-inflammatory activity of commercial cordycepin in LPS stimulated murine BV2 microglia cells for inhibition of NO production as well as PGE2, and pro-inflammatory cytokine release. Cordycepin at $7.5 \mu \mathrm{g} / \mathrm{mL}$, decreased levels of NO production up to $65 \%$ while the PGE2 concentration measured using ELISA kit was also repressed up to $60 \%$. This anti-inflammatory mechanism was found to be due the inhibition of iNOS and COX-2 protein expression. Choi et al. (2014b) also studied the antiinflammatory potential of cordycepin in LPS stimulated RAW 264.7 macrophage cell line for 
NO production, cytokine (TNF- $\alpha$ and IL-1 $\beta$ ) levels and PGE2 production. At $30 \mu \mathrm{g} / \mathrm{mL}$ exposure of induced cells to cordycepin, there was significant decrease in NO, TNF- $\alpha$, IL-1 $\beta$ and PGE2 levels. The mechanism of inhibition was further confirmed by decreased levels of LPS-induced NF- $\mathrm{BB} / \mathrm{p} 65$ levels in the nucleus and inhibition of phosphorylation of IkB- $\alpha$ complex.

\section{Concluding remarks}

The present review focuses on the anti-inflammatory activity of some important worldwide edible, wild and medicinal mushrooms as well as on the bioactive metabolites they contain, which are responsible for the imparted anti-inflammatory activity. Research studies available in literature, on both edible and inedible mushroom species, highlight their anti-inflammatory activity, conclusion drawn mainly based on the extracts evidences and not on the bioactive compounds themselves. Among the existing mushroom species, Agaricus bisporus, Phellinus linteus, Cordyceps species, Antrodia camphorate, Pleurotus species and Ganoderma lucidum have been the most extensively studied.

Nevertheless the intensive research done in field, it is difficult to compare results reported by different researchers, partly due to the diverse methodologies used to evaluate the antiinflammatory activity of both mushroom extracts and isolated compounds. Among them, nitric oxide assay is the most widely used assay for in vitro measurement of NO production in LPS stimulated RAW 264.7 cells. Other methods include in vitro evaluation of TNF- $\alpha$ inhibition in LPS activated THP-1 monocytic cell, measurement of inhibition of expression of iNOS, COX-2 and other pro-inflammatory mediators using cytokine enzyme linked immunosorbent assay (ELISA) kit and COX-1- and COX-2-catalyzed prostaglandin biosynthesis assay. In what concerns in vivo anti-inflammatory studies, many have been carried out by inducing inflammation in mice either by croton oil-induced ear edema test, the 
carrageenin-induced paw edema model, TPA (12-O-tetradecanoylphorbol-13-acetate) induced ear edema or xylene induced edema and the activity of the extracts or compounds evaluated by observed reduction of edema.

Also the $\mathrm{IC}_{50}$ values, concentration responsible for $50 \%$ inhibition of inflammatory mediators production, even for the same mushroom species using the same anti-inflammatory assay, might be different as the bioactive compounds are released depending upon the type of cultivation environment, solvent and extraction procedure, extraction time and mushroom maturation..

Among the several bioactive compounds isolated from mushrooms and studied for antiinflammatory activity, polysaccharides, terpenes and phenolic derivatives are the most implicated and known to show positive bioactivity. Only few research studies reported the bioactivity of ergosterol, fatty acids, glycopeptides, and nucleic acid analogues as well as of other metabolites.

Hence, mushrooms have valuable therapeutic compounds whose mechanism of action need to be fully elucidated and corroborated by conducting clinical trials in order to confirm the effectiveness of some of these mushroom-based inhibitors of NF- $\mathrm{B}$ pathway as well as inhibition of the cyclooxygenase enzyme responsible for expression of many inflammatory mediators. This will consolidate the basis for the development of mushroom-based nutraceuticals or drugs effective against inflammation.

\section{References}

Adebayo E. A., Oloke, J. K., Majolagbe, O. N., Ajani, R. A., \& Bora, T. C. (2012). Antimicrobial and anti-inflammatory potential of polysaccharide from Pleurotus pulmonarius LAU 09. African Journal of Microbiology Research, 6, 3315-3323. 
Akihisa, T., Nakamura, Y., Tagata, M., Tokuda, H., Yasukawa, K., Uchiyama, E., Suzuki, T., \& Kimura, Y. (2007). Ani-inflammatory and anti-tumor-promoting effects of triterpene acids and sterols from the fungus Ganoderma lucidum. Chemistry and Biodiversity, 4, $224-231$.

Alves, M. J., Ferreira, I. C. F. R., Dias, J., Teixeira, V., Martins, A., \& Pintado, M. A. (2012). Review on antimicrobial activity of mushroom (Basidiomycetes) extracts and isolated compounds. Planta Medica, 78, 1707-1718.

Alves, M. J., Ferreira, I. C. F. R., Froufe, H. J. C., Abreu, R. M. V., Martins, A., \& Pintado, M. (2013a). Antimicrobial activity of phenolic compounds identified in wild mushrooms, SAR analysis and docking studies. Journal of Applied Microbiology, 115, 346-357.

Alves, M. J., Ferreira, I. C. F. R., Dias, J., Teixeira, V., Martins, A., \& Pintado, M. (2013b). A review on antifungal activity of mushroom (basidiomycetes) extracts and isolated compounds. Current Topics in Medicinal Chemistry, 13, 2648-2659.

Barros, L., Baptista, P., Correia, D. M., Casal, S., Oliveira, B., \& Ferreira, I. C. F. R. (2007). Fatty acid and sugar compositions, and nutritional value of five wild edible mushrooms from Northeast Portugal. Food Chemistry, 105, 140-145.

Beara, I. N., Lesjak, M. M., Cetojevic -Simin, D. D., Marjanovic, Z. S., Ristic, J. D., Mrkonjic, Z. O., \& Mimica-Dukic, N. M. (2014). Phenolic profile, antioxidant, antiinflammatory and cytotoxic activities of black (Tuber aestivum Vittad.) and white (Tuber magnatum Pico) truffles. Food Chemistry, 165, 460-466.

Bellik, Y., Boukraâ, L., Alzahrani, H. A., Bakhotmah, B. A., Abdellah, F., Hammoudi, S. M., \& Iguer-Ouada, M. (2012). Molecular mechanism underlying anti-inflammatory and anti-allergic activities of phytochemicals: an update. Molecules, 18, 322-353.

Bernardshaw, S., Hetland, G., Ellertsen, L. K., Aaland Tryggestad, A. M., \& Johnson, E. (2005). An extract of the medicinal mushroom Agaricus blazei Murill differentially 
stimulates production of pro-inflammatory cytokines in human monocytes and human vein endothelial cells in vitro. Inflammation, 29, 147-153.

Borchers, A. T., Krishnamurthy, A., Keen, C. L., Meyers, F. J., \& Gershwin, M. E. (2008). The immunobiology of mushrooms. Experimental Biology and Medicine, 233, 259-276.

Bradley, J. R. (2008). TNF- mediated inflammatory disease. Journal of Pathology, 214, 149160.

Buccini, M., Punch, K. A., Kaskow, B., Flematti, G. R., Skelton, B. W., Abraham, L. J., \& Piggott, M. (2014). Ethynylbenzenoid metabolites of Antrodia camphorata: synthesis and inhibition of TNF- $\alpha$ expression. Organic \& Biomolecular Chemistry, 12, 1100-1113.

Cai, T. G., \& Cai, Y. (2011). Triterpenes from the fungus Poria cocos and their inhibitory activity on nitric oxide production in mouse macrophages via blockade of activating protein-1pathway. Chemistry \& Biodiversity, 8, 2135-2143.

Carbonero, E. R., Gracher, A. H. P., Komura, D. L., Marcon, R., Freitas, C. S., Baggio, C. H., Santos, A. R. S., Torri, G., Gorin, P. A. J., \& Iacomini, M. (2008). Lentinus edodes heterogalactan: Antinociceptive and anti-inflammatory effects. Food Chemistry, 111, $531-537$

Carocho, M., \& Ferreira, I. C. F. R. (2013). The role of phenolic compounds in the fight against cancer - A review. Anti-Cancer Agents in Medicinal Chemistry, 13, 1236-1258.

Castro, A. J. G., Castro, L. S. E. P., Santos, M. S. N., Faustino, M. G., Pinheiro, T. S., Dore, C. M. P., Baseia, I. G., \& Leite, E. L. (2014). Anti-inflamatory, anti-angiogenenic and antioxidant activities of polysaccharide-rich extract from fungi Caripia montagnei. Biomedicine \& Preventive Nutrition, 4, 121-129.

Chan, P. M., Kanagasabapathy, G., Tan, Y. S., Sabaratnam, V., \& Kuppusamy, U. R. (2013). Amauroderma rugosum (Blume \& T. Nees) Torrend: Nutritional Composition and 
Antioxidant and Potential Anti-Inflammatory Properties. Evidence-Based Complementary and Alternative Medicine, 2013, 1-10.

Chan, P. M., Tan, Y. S., Chua, K. H., Sabaratnam, V., \& Kuppusamy, U. R. (2015). Attenuation of Inflammatory Mediators (TNF- $\alpha$ and Nitric Oxide) and Up-Regulation of IL-10 by Wild and Domesticated Basidiocarps of Amauroderma rugosum (Blume \& T. Nees) Torrend in LPS-Stimulated RAW264.7 Cells. PLoS ONE, 10, 1-21.

Chang, H. Y., Sheu, M. J., Yang, C. H., Leu, Z. C., Chang, Y. S., Peng, W. H., Huang, S. S., \& Huang, G. J. (2011). Analgesic effects and the mechanisms of anti-inflammation of hispolon in mice. Evidence-Based Complementary and Alternative Medicine, 2011, 1- 8.

Chang, Z. Q., Gebru, E., Lee, S. P., Rhee, M. H., Kim, J. C., Cheng, H., \& Park, S. C. (2011b). In vitro antioxidant and anti-inflammatory activities of protocatechualdehyde isolated from Phellinus gilvus. Journal of nutritional science and vitaminology, 57, 118122.

Chang, C. W., Lur, H. S., Lu, M. K., \& Cheng, J. J. (2013). Sulfated polysaccharides of Armillariella mellea and their anti-inflammatory activities via NF- $\kappa \mathrm{B}$ suppression. Food Research International, 54, 239-245.

Chen, J. N., De Mejia, E. G., \& Wu, J. S. B. (2011). Inhibitory effect of a glycoprotein isolated from golden oyster mushroom (Pleurotus citrinopileatus) on the lipopolysaccharide-induced inflammatory reaction in RAW 264.7 macrophage. Journal of Agricultural and Food Chemistry, 59, 7092-7097

Chen, Y. C., Chiu, H. L., Chao, C. Y., Lin, W. H., Chao, L. K., Huang, G. J., \& Kuo, Y. H. (2013). New anti-inflammatory aromatic components from Antrodia camphorata. International Journal of Molecular Sciences, 14, 4629-4639.

Chen, Y. F., Shiau, A. L., Wang, S. H., Yang, J. S., Chang, S. J., Wu, C. L., \& Wu, T. S. (2014). Zhankuic acid A isolated from Taiwanofungus camphoratus is a novel selective 
TLR4/MD-2 antagonist with anti-inflammatory properties. Journal of Immunology, 192, $2778-2786$.

Chien, S. C., Chen, M. L., Kuo, H. T., Tsai, Y. C., Lin, B. F., \& Kuo, Y. H. (2008). Antiinflammatory activities of new succinic acid maleic derivatives from the fruiting body of Antrodia camphorata. Journal of Agricultural and Food Chemistry, 56, 7017-7022.

Chiocchio, V. M., \& Matković, L. (2011). Determination of ergosterol in cellular fungi by HPLC. A modified technique. Journal of the Argentine Chemical Society, 98, 10-15.

Chiu, C. H., Peng, C. C., Ker, Y. B., Chen, C. C., Lee, A., Chang, W. L., Chyau C. C \& Peng, R. Y. (2014). Physicochemical characteristics and anti-inflammatory activities of a novel glycoprotein, antrodan, isolated from Antrodia cinnamomea mycelia. Molecules, 19: $22-40$.

Choe, J. H., Yi, Y. J., Lee, M. S., Seo, D. W., Yun, B. S., \& Lee, S. M. (2015). Methyl 9Oxo-(10E, 12E)-octadecadienoate Isolated from Fomes fomentarius Attenuates Lipopolysaccharide-Induced Inflammatory Response by Blocking Phosphorylation of STAT3 in Murine Macrophages. Mycobiology, 43, 319-326.

Choi, S., Nguyen, V. T., Tae, N., Lee, S., Ryoo, S., Min, B. S., \& Lee, J. H. (2014a). Antiinflammatory and heme oxygenase-1 inducing activities of lanostane triterpenes isolated from mushroom Ganoderma lucidum in RAW264.7 cells. Toxicology and Applied Pharmacology, 280, 434-442.

Choi, Y. H., Kim, G. Y., \& Lee, H. H. (2014b). Anti-inflammatory effects of cordycepin in lipopolysaccharide-stimulated RAW 264.7 macrophages through Toll-like 4-mediated suppression of mitogen-activated protein kinases and NF-kB signaling pathways. Drug Design and Development Therapy, 8, 1941-1953. 
Chu, C. H., Ye, S. P., Wu, H. C., \& Chiu, C. M. (2015). The Ganoderma Extracts from TeinShan Ganoderma Capsule Suppressed LPS-Induced Nitric Oxide Production in RAW264.7 Cells. MC-Transaction on Biotechnology, 7, 1- 11.

Cirino, G., Distrutti, E., \& Wallace, J. L. (2006). Nitric Oxide and Inflammation. Inflammation \& Allergy-Drug Targets, 5, 115-119.

Corrêa, R. C. G., Souza, A. H. P., Calhelha, R. C., Barros, L., Glamoclija, J., Sokovic, M., . Peralta, R. M., Bracht, A., Ferreira, I. C. F. R. (2015). Bioactive formulations prepared from fruiting bodies and submerged culture mycelia of the Brazilian edible mushroom Pleurotus ostreatoroseus Singer. Food \& Function, 6, 2155-2164.

Debnath, T., Park, S. R., Kim, D. H., Jo, J. E., \& Lim, B. O. (2013). Antioxidant and AntiInflammatory Activity of Polygonatum Sibiricum Rhizome Extracts. Asian Pacific Journal of Tropical Disease, 3, 308-313.

Deng, J. S., Huang, S. S., Lin, T. H., Lee, M. M., Kuo, C. C., Sung, P. J., Hou, W. C., Huang, G. J., \& Kuo, Y. H. (2013). Analgesic and anti-inflammatory bioactivities of eburicoic acid and dehydroeburicoic acid isolated from Antrodia camphorata on the inflammatory mediator expression in mice. Journal of Agricultural and Food Chemistry, 61, 50645071.

Diyabalanage, T., Mulabagal, V., Mills, G., DeWitt, D. L., \& Nair, M. G. (2008). Health beneficial qualities of the edible mushroom, Agrocybe aegerita. Food Chemistry, 108, 97-102.

Dore, C. M. P. G., Azevedo, T. C. G., de Souza, M. C. R., Rego, L. A., de Dantas, J. C. M., Silva, F. R. F Rocha, H. A. O., Leite, E. L. (2007). Anti-inflammatory, antioxidant and cytotoxic actions of beta glucan-rich extract from Geastrum saecatum mushroom. International Immunopharmacology, 7, 1160-1169. 
Dore, C. M. P. G., Alves, M. G. C. F., Santos, M. G. L., de Souza, L. A. R., Baseia I. G., \& Leite, E. L. (2014). Antioxidant and anti-inflammatory properties of an extract rich in polysaccharides of the mushroom Polyporus dermoporus. Antioxidants, 3, 730-744.

Dudhgaonkar, S., Thyagarajan, A., \& Sliva, D. (2009). Suppression of the inflammatory response by triterpenes isolated from the mushroom Ganoderma lucidum. International Immunopharmacology, 9, 1272-1280.

Dugowson, C. E., \& Gnanashanmugam, P. (2006). Nonsteroidal anti-inflammatory drugs. Physical Medicine and Rehabilitation Clinics of North America, 17, 347-354.

El Enshasy, H. A. E., Hatti-Kau, R., (2013). Mushroom immunomodulators: unique molecules with unlimited applications. Trends in Biotechnology, 31, 668-677.

Elsayed, A. E., Hesham, E. L. E., Mohammad, A. M. W., \& Aziz, R. (2014). Mushrooms: A potential natural source of anti-inflammatory compounds for medical applications. Mediators of Inflammation, 2014, 1-15.

Fan, L. P., Ding, S. D., Ai, L. Z., \& Deng, K. Q. (2012). Antitumor and immunomodulatory activity of water-soluble polysaccharide from Inonotus obliquus. Carbohydrate Polymers, 90, 870-874.

Fangkrathok, N., Junlatat, J., Sripanidkulchai, B. (2013). In vivo and in vitro antiinflammatory activity of Lentinus polychrous extract. Journal of Ethnopharmacology, $147,631-637$.

Ferreira, I. C. F. R., Barros, L., \& Abreu, R. M. V. (2009). Antioxidants in wild mushrooms. Current Medicinal Chemistry, 16, 1543-1560.

Ferreira, I. C. F. R., Vaz, J. A., Vasconcelos, M. A., \& Martins, A. (2010). Compounds from wild mushrooms with antitumor potential. Anti-Cancer Agents in Medicinal Chemistry, $10,424-436$. 
Fitzgerald, G. A. (2004). Coxibs and cardiovascular diseases. The New England Journal of Medicine, 351, 1709-1711.

Gebhardt, P., Dornberger, K., Gollmick, F. A., Graefe, U., Haertl, A., Goerls, H., Schlegel, B., \& Hertweck, C. (2007). Quercinol, an anti-inflammatory chromene from the woodrotting fungus Daedalea quercina (oak mazegill). Bioorganic \& Medicinal Chemistry Letters, 17, 2558-2560.

Geethangili, M., \& Tzeng, Y. M. (2011). Review of pharmacological effects of Antrodia camphorata and its bioactive compounds. Evidence-Based Complementary and Alternative Medicine, 2011, 1-17.

Ghazanfari, T., Yaraee, R., Farahnejad, Z., Hakimzadeh, H., \& Danialy, F. (2009). In vitro effect of Pleurotus florida on macrophage cell viability and nitric oxide production. Food and Agricultural Immunology, 20, 105-110.

Grosser, T., Fries, S., \& Fitzgerald, G. A. (2006). Biological basis for the cardiovascular consequences of COX-2 inhibition: therapeutic challenges and opportunities. Journal of Clinical Investigation, 116, 4-15.

Gunawardena, D., Bennett, L., Shanmugam, K., King, K., Williams, R., Zabaras, D., Head, R., Ooi. L., Gyengesi, E., \& Münch, G. (2014). Anti-inflammatory effects of five commercially available mushroom species determined in lipopolysaccharide and interferon $\gamma$ activated murine macrophages. Food Chemistry, 148, 92-96.

Habtemariam, S. (2013). Targeting the production of monocytes/macrophages-derived cytokines by anti-inflammatory herbal drugs. Phytopharmacology, 4, 131-148.

Hämäläinen, M., Nieminen, R., Vuorela, P, Heinonen, M., \& Moilanen, E. (2007). Antiinflammatory effects of flavonoids: genistein, kaempferol, quercetin, and daidzein inhibit STAT-1 and NF-kappaB activations, whereas flavone, isorhamnetin, naringenin, and pelargonidin inhibit only NF-kappaB activation along with their inhibitory effect on 
iNOS expression and NO production in activated macrophages. Mediators of Inflammation, 2007, 1- 10.

Han, E. S., Oh, J. Y., \& Park, H. J. (2011). Cordyceps militaris extract suppresses dextran sodium sulfate-induced acute colitis in mice and production of inflammatory mediators from macrophages and mast cells. Journal of Ethnopharmacology, 134, 703-10.

Han, C., \& Cui, B. (2012). Pharmacological and pharmacokinetic studies with agaricoglycerides, extracted from Grifola frondosa, in animal models of pain and inflammation. Inflammation, 35, 1269-1275.

Han, J. J., Chen, Y. H., Bao, L., Yang, X. L., Liu, D. L., Li, S. J., Zhao, F., \& Liu, H. (2013). Anti-inflammatory and cytotoxic cyathane diterpenoids from the medicinal fungus Cyathus africanus. Fitoterapia, 84, 22-31.

Hasnat, M. A., Pervin, M., Cha, K. M., Kim, S. K., \& Lim, B. O. (2015). Anti-inflammatory activity on mice of extract of Ganoderma lucidum grown on rice via modulation of MAPK and NF-кB pathways. Phytochemistry, 114, 125-136.

Heleno, S. A., Ferreira, I. C. F. R., Calhelha, R. C., Esteves, A. P., \& Queiroz, M. J. R. P. (2014). Cytotoxicity of Coprinopsis atramentaria extract, organic acids and their synthesized methylated and glucuronate derivatives. Food Research International, 55, $170-175$.

Heleno, S. A., Martins, A., Queiroz, M. J. R. P., \& Ferreira, I. C. F. R. (2015). Bioactivity of phenolic acids: Metabolites versus parent compounds: A review. Food Chemistry, 173, $501-513$.

Hirota, M., Morimura, K., \& Shibata, H. (2002). Anti-inflammatory compounds from the bitter mushroom, Sarcodon scabrosus. Bioscience, Biotechnology, and Biochemistry, 66, $179-184$. 
Ho, C. Y., Lau, C. B. S., Kim, C. F., Leung, K. N., Fung, K. P., Tse, T. F., Chan, H. H. L., \& Chow, M. S. S. (2004). Differential effect of Coriolus versicolor (Yunzhi) extract on cytokine production by murine lymphocytes in vitro. International Immunopharmacology, 4, 1549-1557.

Hseu, Y. C., Wu, F. Y., Wu, J. J., Chen, J. Y., Chang, W. H., Lu, F. J., Lai, Y. C., \& Yang, H. L. (2005). Anti-inflammatory potential of Antrodia camphorata through inhibition of iNOS, COX-2 and cytokines via the NF-kB pathway. International Immunopharmacology, 5, 1914-1925.

Hseu, Y. C., Huang, H. C., \& Hsiang, C. Y. (2010). Antrodia camphorata suppresses lipopolysaccharide-induced nuclear factor-kB activation in transgenic mice evaluated by bioluminescence imaging. Food and Chemical Toxicology, 48, 2319-2325.

Hsieh, Y. H., Chu, F. H., Wang, Y. S., Chien, S. C., Chang, S. T., Shaw, J. F., Chen, C. Y., Hsiao, W. W., Kuo, Y. H., \& Wang, S. Y. (2010). Antrocamphin A, an antiinflammatory principal from the fruiting body of Taiwanofungus camphoratus, and its mechanisms. Journal of Agricultural and Food Chemistry, 58, 3153-3158.

Hu, S. H., Wang, J. C., Lien, J. L., Liaw, E. T., \& Lee, M. Y. (2006). Anti-hyperglycemic effect of polysaccharide from fermented broth of Pleurotus citrinopileatus. Applied Microbiology and Biotechnology, 70, 107-113.

Huang, G. J., Huang, S. S., Lin, S. S., Shao, Y. Y., Chen, C. C., Hou, W. C., \& Kuo, Y. H. (2010). Analgesic effects and the mechanisms of anti-inflammation of ergostatrien-3 $\beta$-ol from Antrodia camphorata submerged whole broth in mice. Journal of Agricultural and Food Chemistry, 58, 7445-7452.

Huang, G. J., Huang, S. S., \& Deng, J. S. (2012a). Anti-inflammatory activities of inotilone from Phellinus linteus through the inhibition of MMP-9, NF- $\kappa \mathrm{B}$, and MAPK activation in vitro and in vivo. PLoS One, 7, 1-12. 
Huang, G. J., Pan, C. H., Liu, F. C., Wu, T. S., Wu, C. H. (2012b). Anti-inflammatory effects of ethanolic extract of Antrodia salmonea in the lipopolysaccharide-stimulated RAW246.7 macrophages and the $\lambda$-carrageenan-induced paw edema model. Food and Chemical Toxicology, 50, 1485-1493.

Hur, S. J., Choi, S. Y., \& Lim, B. O. (2012). In vitro anti-inflammatory activity of Russula virescens in the macrophage like cell line RAW 264.7 activated by lipopolysaccharide. Journal of Nutrition \& Food Sciences, 2, 1-4.

Im, K. H., Nguyen, T. K., Shin, D. B., Lee, K. R., \& Lee, T. S. (2014). Appraisal of antioxidant and anti-inflammatory activities of various extracts from the fruiting bodies of Pleurotus Florida. Molecules, 19, 3310-3326.

Imamura, K., Asai, M., Sugamoto, K., Matsumoto, T., Yamasaki, Y., Kamei, I., Hattori, T., Kishimoto, M., Niisaka, S., Kubo, M., Nishiyama, K., \& Yamasaki, M. (2015). Suppressing effect of cordycepin on the lipopolysaccharide-induced nitric oxide production in RAW 264.7 cells. Bioscience, Biotechnology, and Biochemistry, 79, 10211025.

Ito, T., Kato, M., Tsuchida, H., Harada, E., Niwa, T., \& Osawa, T. (2011). Ergothioneine as an anti-oxidative/anti-inflammatory component in several edible mushrooms. Food Science and Technology Research, 17, 103-110.

Jedinak, A., Dudhgaonkar, S., Wu, Q. L., Simon, J., \& Sliva, D. (2011). Anti-inflammatory activity of edible oyster mushroom is mediated through the inhibition of NF- $\kappa \mathrm{B}$ and AP1 signaling. Nutrition Journal, 10, 1-10.

Jeong, J. W., Jin, C. Y., Kim, G. Y., Lee, J. D., Park, C., Kim, G. D., Kim, W. J., Jung, W. K., Seo, S. K., Choi, I. W., \& Choi, Y. H. (2010). Anti-inflammatory effects of cordycepin via suppression of inflammatory mediators in BV2 microglial cells. International Immunopharmacology, 10, 1580- 1586. 
Jeong, J. W., Lee, H. H., Han, M. H., Kim, G. Y., Hong, S. H., Park, C., Choi, Y. H. (2014) Ethanol extract of Poria cocos reduces the production of inflammatory mediators by suppressing the NF-kappaB signalling pathway in lipopolysaccharide-stimulated RAW 264.7 macrophages. BMC Complementary and Alternative Medicine, 14, 1-8.

Joo, M, \& Sadikot, R. T. (2012) PGD synthase and PGD2 in immune resposne. Mediators of Inflammation, 2012, 1-6.

Joo, T., Sowndhararajan, K., Hong, S., Lee, J., Park, S. Y., Kim, S., \& Jhoo, J. W. (2014). Inhibition of nitric oxide production in LPS-stimulated raw 264.7 cells by stem bark of Ulmus pumila L. Saudi Journal of Biological Sciences, 21, 427-435.

Jose, N., Ajith, T. A., \& Jananrdhanan, K. K. (2004). Methanol extract of the oyster mushroom, Pleurotus florida, inhibits inflammation and platelet aggregation. Phytotherapy Research, 18, 43-46.

Joseph, S., Janardhanan, K. K., George, V., \& Sabulal, B. (2011). A new epoxidic ganoderic acid and other phytoconstituents from Ganoderma lucidum. Phytochemistry Letters, 4, $386-388$.

Joung, H. J., Kim, Y. S., Hwang, J. W., Han, Y. K., Jeong, J. H., Lee, J. S., Moon, S. H., Jeon, B. T., \& Park, P. J. (2014). Anti-inflammatory effects of extract from Haliotis discus hannai fermented with Cordyceps militaris mycelia in RAW264.7 macrophages through TRIF-dependent signalling pathway. Fish and Shellfish Immunology, 38, 184189.

Jung, S. H., Kim, S. J., Jun, B. G., Lee, K. T., Hong, S. P., \& Oh, M. S. (2013). A-Cyperone, isolated from the rhizomes of Cyperus rotundus, inhibits LPS-induced COX-2 expression and PGE2 production through the negative regulation of NF- $\mathrm{BB}$ signalling in RAW 264.7 cells. Journal of Ethnopharmacology, 147, 208-214. 
Kalač, P. (2013). A review of chemical composition and nutritional value of wild-growing and cultivated mushrooms. Journal of the Science of Food and Agriculture, 93, 209-218.

Kamo, T., Asanoma, M., Shibata, H., \& Hirota, M. (2003). Anti-inflammatory LanostaneType Triterpene Acids from Piptoporus betulinus. Journal of Natural Products, 66, $1104-1106$.

Kamo, T., Imura, Y., Hagio, T., Makabe, H., Shibata, H., \& Hirota, M. (2004). Antiinflammatory cyathane diterpenoids from Sarcodon scabrosus. Bioscience, Biotechnology, and Biochemistry, 68, 1362-1365.

Kanwar, J. R., Kanwar, R. K., Burrow, H., \& Baratchi, S. (2009). Recent advances on the roles of NO in cancer and chronic inflammatory disorders. Current Medicinal Chemistry, $16,2373-2394$.

Kemami, Wangun, H. V., Berg, A., Hertel, W., Nkengfack, A. E., \& Hertweck, C. (2004). Anti-inflammatory and Anti-hyaluronate Lyase Activities of Lanostanoids from Piptoporus betulinus. The Journal of Antibiotics, 57, 755-758.

Kim, K. M., Kwon, Y. G., Chung, H. T., Yun Y. G., Pae, H. O., Han, J. A. Ha, K. S., Kim, T. W., \& Kim, Y. M. (2003). Methanol extract of Cordyceps pruinosa inhibits in vitro and

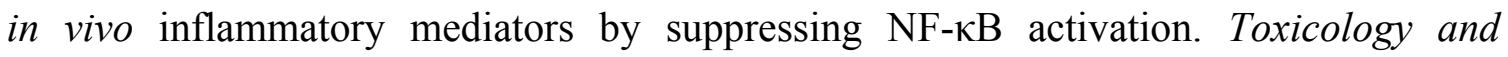
Applied Pharmacology, 190, 1-8.

Kim, S. H., Song, Y. S., Kim, S. K., Kim, B. C., Lim, C. J., \& Park, E. H. (2004). Antiinflammatory and related pharmacological activities of the $\mathrm{n}-\mathrm{BuOH}$ subfraction of mushroom Phellinus linteus. Journal of Ethnopharmacology, 93, 141-146.

Kim, B. C., Choi, J. W., Hong, H. Y., Lee, S. A., Hong, S., Park, E. H., Kim, S. J., \& Lim, C. J. (2006). Heme oxygenase-1 mediates the anti-inflammatory effect of mushroom Phellinus linteus in LPS-stimulated RAW264.7 macrophages. Journal of Ethnopharmacology, 106, $364-371$. 
Kim, B. C., Jeon, W. K., Hong, H. Y., Jeon, K. B., Hahn, J. H., Kim, Y. M., Numazawa, S., Yosida, T., Park, E. H., \& Lim, C. J. (2007). The anti-inflammatory activity of Phellinus linteus (Berk. \&M.A. Curt.), mediated through the PKCdelta/Nrf2/ARE signaling to upregulation of heme oxygenase-1. Journal of Ethnopharmacology, 113, 240-247.

Kim, M. J., Lee, H. H., Jeong, J. W., Seo, M. J., Kang, B. W., Park, J. U., Kim, K. S., Cho, Y. S., Seo, K. I., Kim, G. I., Kim, J. I., Choi, Y. H., \& Jeong, Y. K. (2014). Antiinflammatory effects of 5-hydroxy-3, 6, 7, 8, 3', 4' -hexamethoxyflavone via NF-kappaB inactivation in lipopolysaccharide-stimulated RAW 264.7 macrophage. Molecular Medicine Reports. 9, 1197-1203.

Kobori, M., Yoshida, M., Ohnishi-Kameyama, M., \& Shinmoto, H. (2007). Ergosterol peroxide from an edible mushroom suppresses inflammatory responses in RAW264.7 macrophages and growth of HT29 colon adenocarcinoma cells. British Journal of Pharmacology, 150, 209- 219.

Kohno, K., Miyake, M., Sano, O., Tanaka-Kataoka, M., Yamamoto, S., KoyaMiyata, S., Arai, N., Fujii, M., Watanabe, H., Ushio, S., Iwaki, K., \& Fukuda, S. (2008). Antiinflammatory and immunomodulatory properties of 2-amino- 3H-phenoxazin-3-one. Biological and Pharmaceutical Bulletin, 31, 1938-1945.

Komura, D. L., Carbonero, E. R., Gracher, A. H. P., Baggio, C. H., Freitas, C. S., Marcon, R., Santos, A. R. S., Gorin, P. A. J., \& Iacomini, M. (2010). Structure of Agaricus spp. fucogalactans and their anti-inflammatory and antinociceptive properties. Bioresource Technology, 101, 6192-6199.

Kuo, Y. C., Lai, C. S., Wang, J. M., Badmaev, V., Nagabhushanam, K., Ho, C. T., \& Pan M. H. (2009). Differential inhibitory effects of inotilone on inflammatory mediators, inducible nitric oxide synthase and cyclooxygenase-2, in LPS-stimulated murine macrophage. Molecular Nutrition \& Food Research, 53, 1386-1395. 
Kuo, C. F., Hsieh, C. H., \& Lin, W. Y. (2011). Proteomic response of LAP-activated RAW 264.7 macrophages to the anti-inflammatory property of fungal ergosterol. Food Chemistry, 126, 207-212.

Lavi, I., Levinson, D., Peri I., Hadar Y., \& Schwartz, B. (2010). Orally administered glucans from the edible mushroom Pleurotus pulmonarius reduce acute inflammation in dextran sulfate sodium induced experimental colitis. British Journal of Nutrition, 103, 393-402.

Lau, B. F., Abdullah, N., Aminudin, N., Lee, H. B., \& Tan, P. J. (2015). Ethnomedicinal uses, pharmacological activities, and cultivation of Lignosus spp. (tiger's milk mushrooms) in Malaysia - a review. Journal of Ethnopharmacology, 169, 441-458.

Lee, Y.G., Lee, W.M., Kim, J.Y., Lee, J.Y., Lee, I.K., Yun, B.S., Rhee, M.H., \& Cho, J.Y. (2008). Src kinase targeted anti-inflammatory activity of davallialactone from Inonotus xeranticus in lipopolysaccharide-activated RAW264.7 cells. British Journal of Pharmacology, 154, 852-63.

Lee, B. R., Kim, S. Y., Kim, D. W., An, J. J., Song, H. Y., Yoo, K. Y., Kang, T. C., Won, M. H., Lee, K. J., Kim, K. H., Joo, J. H., Ham, H. J., Hur, J. H., Cho, S. W., Han K. H., Lee, K. S., Park, H., Choi, S. Y., \& Eum, W. S. (2009). Agrocybe chaxingu polysaccharide prevents inflammation through the inhibition of COX-2 and NO production. $B M B$ Reports, 42, 794-799.

Lee, N. H., Lee, Y. H., Bhattari, G., Lee, I. K., Yun, B. S., Jeon, J. G., Hwang, P. H., Yi, H. K. (2011a). Reactive oxygen species removal activity of davallialactone reduces lipopolysaccharide induced pulpal inflammation through inhibition of the extracellular signal-regulated kinase 1/2 and nuclear factor kappa B pathway. Journal of Endodontics, $37,491-495$

Lee, C. L., Huang, C. H., Wang, H. C., Chuang, D. W., Wu, M. J., Wang, S. Y., Hwang, T. L., Wu, C. C., Chen, Y. L.,Chang, F. R., Wu, Y. C. (2011b). First total synthesis of 
antrocamphin $\mathrm{A}$ and its analogs as anti-inflammatory and anti-platelet aggregation agents. Organic \& Biomolecular Chemistry, 9, 70-73.

Lee, Y. R., Kim, K. M., Jeon, B. H., Choi, J. W., \& Choi, S. (2012). The n-butanol fraction of Naematoloma sublateritium suppresses the inflammatory response through downregulation of NF-kappaB in human endothelial cells. International Journal of Molecular Medicine, 29, 801-808.

Lee, Y. H., Lee, N. H., Bhattarai, G., Kim, G. E., Lee, I. K., Yun, B. S., Hwang, P. H., \& Yi, H. K. (2013). Anti-inflammatory effect of pachymic acid promotes odontoblastic differentiation via HO-1 in dental pulp cells. Oral Disease, 19, 193-199.

Lee, S. S., Tan, N. H., Fung, S. Y., Sim, S. M., Tan, C. S., \& Ng, S. T. (2014). Antiinflammatory effect of the sclerotium of Lignosus rhinocerotis (Cooke) Ryvarden, the Tiger Milk mushroom. BMC complementary and alternative medicine, 14, 1-8.

Li, Y. X., Bao, L., Song, B., Han, J. J., Li, H. R., Zhao, F., \& Liu, H. (2013). A new benzoquinone and a new benzofuran from the edible mushroom Neolentinus lepideus and their inhibitory activity in NO production inhibition assay. Food Chemistry, 141, $1614-1618$.

Li, H., Lee, H. S., Kim, S. H., Moon, B., \& Lee.C. (2014a). Antioxidant and Anti-Inflamatory Activities of Methanol Extracts of Tremella fuciformis and Its Major Phenolic Acids. Journal of Food Science, 79, 460-468.

Li, W., Zhou, W., Lee, D. S., Shim, S. H., Kim, Y. C., Kim, Y. H. (2014b). Hericirine, a novel anti-inflammatory alkaloid from Hericium erinaceum. Tetrahedron Letters, 55, 4086-4090.

Li, W., Zhou, W., Cha, J. Y., Kwon, S. U., Baek, K. H., Shim, S. H., Lee, Y. M., \& Kim, Y. H. (2015). Sterols from Hericium erinaceum and their inhibition of TNF- $\alpha$ and NO 
production in lipopolysaccharide induced RAW 264.7 cells. Phytochemistry, 115, 231238.

Liao, Y. R., Kuo, P. C., Liang, J. W., Shen, Y. C., \& Wu, T. S. (2012). An efficient total synthesis of a potent anti-inflammatory agent, Benzocamphorin $\mathrm{F}$, and its antiinflammatory activity. International Journal of Molecular Sciences, 13, 10432-10440.

Lim, H. W., Yoon, J. H. Kim, Y. S. Lee, M. W. Park S. Y., \& Choi. H. K. (2007). Free radical-scavenging and inhibition of nitric oxide production by four grades of pine mushroom (Tricholoma matsutake Sing.). Food Chemistry, 103, 1337-1342.

Lim, B. O. (2011). Coriolus versicolor Suppresses Inflammatory Bowel Disease by Inhibiting the Expression of STAT1 and STAT6 Associated with IFN- $\gamma$ and IL-4 Expression. Phytotherapy Research, 25, 1257-1261.

Lin, J. T., Liu, C. W., Chen, Y. C., Hu, C. C., Juang, L. D., Shiesh, C. C., \& Yang, D. J. (2014a) Chemical composition, antioxidant and anti-inflammatory properties for ethanolic extracts from Pleurotus eryngii fruiting bodies harvested at different time. LWT- Food Science and Technology, 55, 374-382.

Lin, C. J., Lien, H. M., Chang, H. Y., Huang, C. L., Liu, J. J., Chang, Y. C., Chen, C. C., \& Lai, C. H. (2014b). Biological evaluation of Phellinus linteus - fermented broths as antiinflammatory agents. Journal of Bioscience and Bioengineering, 118, 88-93.

Lin, M. K., Lee, M. S., Chang, W. T., Chen, H. Y., Chen, J. F., Li, Y. R., Lin, C. C., \& Wu, T. S. (2015). Immunosuppressive effect of zhankuic acid C from Taiwanofungus camphoratus on dendritic cell activation and the contact hypersensitivity response. Bioorganic \& Medicinal Chemistry Letters, 25, 4637-4641.

Lindequist, U., Niedermeyer, T. H., \& Julich, W. D. (2005). The pharmacological potential of mushrooms. Evidence-based Complementary and Alternative Medicine, 2, 285-299. 
Liu, D. Z., Liang, H. J., Chen, C. H., Su, C. H., Lee, Z. H., Huang, C. T., Hou, W. C., Lin, S. Y., Zhong, W. B., Lin, P. J., Hung, L. F., \& Liang, Y. C. (2007). Comparative antiinflammatory characterization of wild fruiting body, liquid-state fermentation, and solidstate culture of Taiwanofungus camphoratus in microglia and the mechanism of its action. Journal of Ethnopharmacology, 113, 45-53.

Liu, Y. W., Mei, H. C., Su, Y. W., Fan, H. T., Chen, C. C., \& Tsai, Y. C. (2014). Inhibitory effects of Pleurotus tuber-regium mycelia and bioactive constituents on LPS-treated RAW264.7 cells. Journal of Functional Foods, 7, 662-670.

Liu, C., Yang, N., Song, Y., Wang, L., Zi, J., Zhang, S., Dunkin, D., Busse, P., Weir, D., Tversky, J., Miller, R. L., Goldfarb, J., Zhan, J., \& Li, X. M. (2015). Ganoderic acid C1 isolated from the anti-asthma formula, ASHMITM suppresses TNF- $\alpha$ production by mouse macrophages and peripheral blood mononuclear cells from asthma patients. International Immunopharmacology, 27, 224-231.

Lu, Y. Y., Ao, Z. H., Lu, Z. M., Xu, H. Y., Zhang, X. M., Dou, W. F., \& Xu, Z. H. (2008). Analgesic and anti-inflammatory effects of the dry matter of culture broth of Termitomyces albuminosus and its extracts. Journal of Ethnopharmacology, 120, 432436.

Lu, M. C., El-Shazly, M., Wu, T. Y., Du, Y. C., Chang, T. T., Chen, C. F., Hsu, Y. M., Lai, K. H., Chiu, C. P., Chang, F. R., \& Wu, Y. C. (2013). Recent research and development of Antrodia cinnamomea. Pharmacology \& Therapeutics, 139, 124-156.

Lu, M. Y., Chen, C. C., Lee, L. Y., Lin, T. W., \& Kuo, C. F. (2015) N6 (2-Hydroxyethyl) adenosine in the Medicinal Mushroom Cordyceps cicadae Attenuates Lipopolysaccharide-Stimulated Pro-inflammatory Responses by Suppressing TLR4Mediated NF-кB Signaling Pathways. Journal of Natural Products, 78, 2452-2460. 
Ma, L., Chen, H., Dong, P., \& Lu, X. (2013). Anti-inflammatory and anticancer activities of extracts and compounds from the mushroom Inonotus obliquus. Food Chemistry, 139, $503-508$.

Meek, I. L., van de Laar, M. A., \& Vonkeman, H. E. (2010). Non-steroidal anti-inflammatory drugs: an overview of cardiovascular risks. Pharmaceuticals, 3, 2146-2162.

Michalak, A. (2006). Phenolic compounds and their antioxidant activity in plants growing under heavy metal stress. Polish Journal of Environmental Studies, 15, 523-530.

Mizuno, M., Nishitani, Y., Hashimoto, T., \& Kanazawa, K. (2009). Different suppressive effects of fucoidan and lentinan on IL-8 mRNA expression in in vitro gut inflammation. Bioscience, Biotechnology, and Biochemistry, 3, 2324-2325.

Moradali, M. F., Mostafavi, H., Ghods, S., \& Hedjaroude, G. A. (2007). Immunomodulating and anticancer agents in the realm of macromycetes fungi (macrofungi). International Immunopharmacology, 7, 701-724.

Mourão, F., Umeo, S. H., Bertéli, M. B. D., Lourenço, E. L., Gasparotto, A., Takemura, O. S., Linde, G. A., \& Colauto, N. B. (2011). Anti-inflammatory activity of Agaricus blazei in different basidiocarp maturation phases. Food and Agricultural Immunology, 22, 325333.

Mori, K., Kobayashi, C., Tomita, T., Inatomi, S., \& Ikeda, M. (2008). Antiatherosclerotic effect of the edible mushrooms Pleurotus eryngii (Eringi), Grifola frondosa (Maitake), and Hypsizygus marmoreus (Bunashimeji) in apolipoprotein edeficient mice. Nutrition Research, 28, 335-342.

Moro, C., Palacios, I., Lozano, M., D'Arrigo, M., Guillamón, E., Villares, A., Martínez, J. A., \& García-Lafuente, A. (2012). Antiinflammatory activity of methanolic extracts from edible mushrooms in LPS activated RAW 264.7 macrophages. Food Chemistry, 130, $350-355$. 
Nascimento, M. S., Magalhães, J. E. M., Pinheiro, T. S., Silva, T. A., Coutinho, L. G., Baseia, I. G., Lima, L. F. A., \& Leite, E. L. (2012). Polysaccharides from the fungus Scleroderma nitidum with anti-inflammatory potential modulate cytokine levels and the expression of nuclear factor $\kappa \mathrm{B}$. Brazilian Journal of Pharmacognosy, 22, 60-68.

Noreen, Y., Ringbom, T., Perera, P., Danielson, H., \& Bohlin, L. (1998). Development of a radiochemical cyclooxygenase- 1 and -2 in vitro assay, for identification of natural products as inhibitors of prostaglandin biosynthesis. Journal of Natural Products, 61, 27.

Nowak, J.Z. (2012). Non-steroidal anti-inflammatory drugs (NSAIDs) in ophthalmology: pharmacological and clinical characteristics. Military Pharmacy and Medicine, 5, 33-50.

Pacheco-Sanchez, M., Boutin, Y., Angers, P., Gosselin, A., \& Tweddell, R. J. (2006). A bioactive $(1 \rightarrow 3)$, $(1 \rightarrow 4) \beta$-D-glucan from Collybia dryophila and other mushrooms. Mycologia, 98, 180-185.

Padilha, M. M., Avila, A. A., Sousa, P. J., Cardoso, L. G., Perazzo, F. F., \& Carvalho, J. C. (2009). Anti-inflammatory activity of aqueous and alkaline extracts from mushrooms (Agaricus blazei Murill). Journal of Medicinal Food, 12, 359-364.

Park, Y. M., Won, J. H., Kim, Y. H., Choi, J. W., Park, H. J., Lee, K. T. (2005). In vivo and in vitro anti-inflammatory and anti-nociceptive effects of the methanol extract of Inonotus obliquus. Journal of Ethnopharmacology, 101, 120-128

Phillips, K. M., Ruggio D. M., Horst R. L., Minor B, Simon R. R., Feeney M. J., Byrdwell, W. C., \& Haytowitz, D. B. (2011). Vitamin D and sterol composition of 10 types of mushrooms from retail suppliers in the United States. Journal of Agricultural and Food Chemistry, 59, 7841-7853. 
Puttaraju, N. G., Venkateshaiah, S. U., Dharmesh, S. M., Urs, S. M., \& Somasundaram, R. (2006). Antioxidant activity of indigenous edible mushrooms. Journal of Agricultural and Food Chemistry, 54, 9764-9772.

Qian, G., Pan, G. F., \& Guo, J. Y. (2012). Anti-inflammatory and antinociceptive effects of cordymin, a peptide purified from the medicinal mushroom Cordyceps sinensis. Natural Product Research, 26, 2358-2362.

Quang, D. N., Harinantenaina, L., Nishizawa, T., Hashimoto, T., Kohchi, C., Soma, G. I., \& Asakawa, Y. (2006). Inhibitory activity of nitric oxide production in RAW 264.7 cells of daldinals A-C from the fungus Daldinia childiae and other metabolites isolated from inedible mushrooms. Journal of Natural Medicines, 60, 303-307.

Quang, D. N., Hashimoto, T., Arakawa, Y., Kohchi, C., Nishizawa, T., Soma, G. I., \& Asakawa, Y. (2006). Grifolin derivatives from Albatrellus caeruleoporus, new inhibitors of nitric oxide production in RAW 264.7 cells. Bioorganic \& Medicinal Chemistry, 14, $164-168$.

Queiroz, L. S., Nascimento, M. S., Cruz, A. K. M., Castro, A. J. G., Moura, M. F. V., Baseia, I. G., Araújo, R. M., Benevides, N. M. B., Lima, L. F. A., \& Leite, E. L. (2010). Glucans from the Caripia montagnei mushroom present anti-inflammatory activity. International Immunopharmacology, 10, 34-42.

Rao, Y. K., Fang, S. H., Wu, W. S., \& Tzeng, Y. M. (2010). Constituents isolated from Cordyceps militaris suppress enhanced inflammatory mediator's production and human cancer cell proliferation. Journal of Ethnopharmacology, 131, 363-367.

Rao, Y. K., Fang, S. H., \& Tzeng, Y. M. (2007). Evaluation of the anti-inflammatory and antiproliferation tumoral cells activities of Antrodia camphorata, Cordyceps sinensis, and Cinnamomum osmophloeum bark extracts. Journal of Ethnopharmacology, 114, 7885. 
Reis, F. S., Barros, L., Martins, A., \& Ferreira, I. C. F. R. (2012). Chemical composition and nutritional value of the most widely appreciated mushrooms: an inter-species comparative study. Food and Chemical Toxicology, 50, 191-197.

Ren, .J, Shi, J. L., Han, C., Liu, Z. Q., \& Guo, J. (2012). Isolation and biological activity of triglycerides of the fermented mushroom of Coprinus comatus. BMC Complementary and Alternative Medicine, 12, 1-5.

Ruimi, N., Petrova, R. D., Agbaria, R., Sussan, S., Wasser, S. P., Reznick, A. Z., \& Mahajna, J. (2010a). Inhibition of TNF $\alpha$-induced iNOS expression in HSV-tk transduced 9L glioblastoma cell lines by Marasmius oreades substances through NF- $\mathrm{kB}$ - and MAPKdependent mechanisms. Molecular Biology Reports, 37, 380-3812.

Ruimi, N., Rwashdeh, H., Wasser, S. P., Konkimalia, B., Efferth, T., Borgatti, M., Gambari, R., \& Mahajna, J. (2010b). Daedalea gibbosa substances inhibit LPS-induced expression of iNOS by suppression of NF-kB and MAPK activities in RAW 264.7 macrophage cells. International Journal of Molecular Medicine, 25, 421-432.

Ruiz, P. A., \& Haller, D. (2006). Functional diversity of flavonoids in the inhibition of the proinflammatory NF-kappaB, IRF, and Akt signaling pathways in murine intestinal epithelial cells. Journal of Nutrition, 136, 664-671.

Ruthes, A. C., Carbonero, E. R., Cordova, M. M., Baggio, C. H., Santos, A. R., Sassaki, G. L., Cipriani, T. R., Gorin P. A. J., \& Iacomini M. (2013a). Lactarius rufus $(1 \rightarrow 3)$, $(1 \rightarrow 6)$ - $\beta$-D-glucans: structure, antinociceptive and anti-inflammatory effects. Carbohydrate Polymers, 94, 129- 136

Ruthes, A. C., Rattmann, Y. D., Malquevicz-Paiva, S. M., Carbonero, E. R., Cordova, M. M., Baggio, C. H., Santos, A. R. S., Gorin, P. A. J., \& Iacomini, M. (2013b). Agaricus bisporus fucogalactan: Structural characterization and pharmacological approaches. Carbohydrate Polymers, 92, 184-191. 
Ruthes, A. C., Carbonero, E. R., Córdova, M. M., Baggio, C. H., Sassaki, G. L., Gorin, P. A. J., Santos, A.R.S., \& Iacomini, M. (2013c). Fucomannogalactan and glucan from mushroom Amanita muscaria: Structure and inflammatory pain inhibition. Carbohydrate Polymers, 98, 761-769.

Saad, W. Z., Hashim, M., Ahmad, S., \& Abdullah, N. (2014). Effects of heat treatment on total phenolic contents, antioxidant and anti-inflammatory activities of Pleurotus sajorcaju extract. International Journal of Food Properties 17, 219-225.

Saba, E., Son, Y., Jeon, B. R., Kim, S. E., Lee, I. K., Yun, B. S., \& Rhee, M. H. (2015). Acetyl Eburicoic Acid from Laetiporus sulphurous var. miniatus Suppresses Inflammation in Murine Macrophage RAW 264.7 Cells. Mycobiology, 43, 131-136.

Shao, H. J., Jeong, J. B., Kim, K. J., \& Lee, S. H. (2015). Anti-inflammatory activity of mushroom-derived hispidin through blocking of NF- $\mathrm{KB}$ activation. Journal of the Science of Food and Agriculture, 95, 2482-2486.

Sharma, J. N., Al-Omran, A., \& Parvathy, S. S. (2007). Role of nitric oxide in inflammatory diseases. Inflammopharmacology, 15, 252-259.

Shin, S., Lee, S., Kwon, J., Moon, S., Lee, C. K., Cho, K., Ha, N. J., \& Kim, K. (2009). Cordycepin Suppresses Expression of Diabetes Regulating Genes by Inhibition of Lipopolysaccharide-induced Inflammation in Macrophages. Immune Network, 9, 98105.

Shukla, S., Bafna, K., Sundar, D., \& Thorat, S. S. (2014). The bitter barricading of prostaglandin biosynthesis pathway: understanding the molecular mechanism of selective cyclooxygenase-2 inhibition by amarogentin, a secoiridoid glycoside from Swertia chirayita. PLoS One, 9, 1-15.

Silveira, M. L. L., Smiderle, F. R., Moraes, C. P., Borato, D. G., Baggio, C. H., Ruthes, A. C., Wisbeck, E., Sassaki, G. L., Cipriani, T. R., Furlan, S. A., \& Iacomini, M. (2014). 
Structural characterization and anti-inflammatory activity of a linear $\beta$-d-glucan isolated from Pleurotus sajor-caju. Carbohydrate Polymers, 113, 588-596.

Silveira, M. L. L., Smiderle, F. R., Agostini, F., Pereira, E. M., Wisbeck, E., Bonatti-Chaves, M., Ruthes, A.C., Sassaki, G.L., Cipriani, T. R., Furlan, S. A., \& Iacomini, M (2015). Exopolysaccharide produced by Pleurotus sajor-caju: Its chemical structure and antiinflammatory activity. International Journal of Biological Macromolecules, 75, 90-96.

Smiderle, F. R., Olsen, L. M., Carbonero, E. R., Baggio, C. H., Freitas, C. S., Marcon, R., Santos, A. R. S., Gorin, P. A. J., \& Iacomini, M. (2008). Anti-inflammatory and analgesic properties in a rodent model of a $(1->3),(1->6)$-linked $\beta$-glucan isolated from Pleurotus pulmonarius. European Journal of Pharmacology, 597, 6-91.

Smiderle, F. R., Baggio, C. H., Borato, D. G., Santana-Filho, A. P., Sassaki, G. L. Iacomini, M., van Griensven, L. J. L. D. (2014). Anti-inflammatory properties of the medicinal mushroom Cordyceps militaris might be related to its linear (1-3)- $\beta$-D-Glucan. PLoS ONE, 9, 1-11.

Song, H. H., Chae, H. S., Oh, S. R., Lee, H. K., \& Chin, Y. W. (2012). Anti-inflammatory and anti-allergic effect of Agaricus blazei extract in bone marrow-derived mast cells. American Journal of Chinese Medicine, 40, 1073-1084.

Song, M., \& Park, H. J. (2014). Anti-inflammatory effect of Phellinus linteus grown on germinated brown rice on dextran sodium sulfate-induced acute colitis in mice and LPSactivated macrophages. Journal of Ethnopharmacology, 154, 311-318.

Stanikunaite, R., Khan, S. I., Trappe, J. M., \& Ross, S. A. (2009). Cyclooxygenase-2 inhibitory and antioxidant compounds from the truffle Elaphomyces granulatus. Phytotherapy Research, 23, 575-578.

Streck, G. (2009). Chemical and biological analysis of estrogenic, progestagenic and androgenic steroids in the environment. Trends in Analytical Chemistry, 28, 635-652. 
Taofiq, O., Calhelha, R. C., Heleno, S. A., Barros, L., Martins, A., Santos-Buelga, C., Queiroz, M. J. R. P., \& Ferreira, I. C. F. R. (2015). The contribution of phenolic acids to the anti-inflammatory activity of mushrooms: Screening in phenolic extracts, individual parent molecules and synthesized glucuronated and methylated derivatives. Food Research International, 76, 821-827.

Tung, N. T., Cuong, T. D., Hung, T. M., Lee, J. H., Woo, M. H., Choi, J. S., Kim, J., Ryu, S. H., \& Min, B. S. (2013). Inhibitory effect on NO production of triterpenes from the fruiting bodies of Ganoderma lucidum. Bioorganic \& Medicinal Chemistry Letters, 23, $1428-32$.

Van, Q., Nayak, B. N., Reimer, M., Jones, P. J. H., Fulcher, R. G., \& Rempel, C. B. (2009). Anti-inflammatory effect of Inonotus obliquus, Polygala senega L., and Viburnum trilobum in a cell screening assay. Journal of Ethnopharmacology, 125, 487-493.

Villares, A. (2013). Polysaccharides from the edible mushroom Calocybe gambosa: structure and chain conformation of a $(1 \rightarrow 4),(1 \rightarrow 6)$-linked glucan. Carbohydrate Research, 375, $153-157$.

Wang, X, Hu D, Zhang L, Lian G, Zhao S, Wang C, Yin. J., Wu, C., \& Yang, J. (2013a) Gomisin A inhibits lipopolysaccharide-induced inflammatory responses in N9 microglia via blocking the NF-кB/MAPKs pathway. Food and Chemical Toxicology, 63, 119-127.

Wang, P., Li, X. T., Sun, L., \& Shen, L. (2013b). Anti-inflammatory activity of water-soluble polysaccharide of Agaricus blazei Murill on ovariectomized osteopenic rats. EvidenceBased Complementary and Alternative Medicine, 2013, 1-5.

Wang, Q., Kuang, H., Su, Y., Sun, Y., Feng, J., Guo, R., \& Chan, K. (2013c). Naturally derived anti-inflammatory compounds from Chinese medicinal plants. Journal of Ethnopharmacology, 146, 9-39. 
Wen, C. L., Chang, C. C., Huang, S. S., Kuo, C. L., Hsu, S. L., Deng, J. S., \& Huang, G. J. (2011). Anti-inflammatory effects of methanol extract of Antrodia cinnamomea mycelia both in vitro and in vivo. Journal of Ethnopharmacology, 137, 575-584.

Won, S. Y., \& Park, E. H. (2005) Anti-inflammatory and related pharmacological activities of cultured mycelia and fruiting bodies of Cordyceps militaris. Journal of Ethnopharmacology, 96, 555-561.

Wu, M. D., Cheng, M. J., Wang, B. C., Yech, Y. J., Lai, J. T., Kuo, Y. H., Yuan, G. F., \& Chen, I. S. (2008). Maleimide and maleic anhydride derivatives from the mycelia of Antrodia cinnamomea and their nitric oxide inhibitory activities in macrophages. Journal of Natural Products, 71, 1258-1261.

Wu, S. J., Lu, T. M., Lai, M. N., \& Ng, L. T. (2013a). Immunomodulatory activities of medicinal mushroom Grifola frondosa extract and its bioactive constituent. American Journal of Chinese Medicine, 41, 131-144,

Wu, M. D., Cheng, M. J., Yech, Y. J., Yuan, G. F., \& Chen, J. J. (2013b). Inhibitory effects of maleimide derivatives from the mycelia of the fungus Antrodia cinnamomea BCRC 36799 on nitric oxide production in lipopolysaccharide (LPS)-activated RAW264.7 macrophages. Chemistry \& Biodiversity, 10, $434-441$.

Wu, J. Y., Chen, X., \& Siu, K. C. (2014). Isolation and structure characterization of an antioxidative glycopeptide from mycelial culture broth of a medicinal fungus. International Journal of Molecular Sciences, 15, 17318-17332.

Xu, X., Yasuda, M., Nakamura-Tsuruta, S., Mizuno, M., \& Ashida, H. (2012). $\beta$-Glucan from Lentinus edodes inhibits nitric oxide and tumor necrosis factor- $\alpha$ production and phosphorylation of mitogen-activated protein kinases in lipopolysaccharide stimulated murine RAW 264.7 macrophages. Journal of Biological Chemistry, 287, 871-878. 
Xu, Z. Y., Yan, S., Bi, K. S., Han, J. J., Chen, Y. H., \& Wu, Z. A. (2013). Isolation and identification of a new anti-inflammatory cyathane diterpenoid from the medicinal fungus Cyathus hookeri berk. Fitoterapia, 86, 159-162.

Yang, L. Y., Shen, S. C., Cheng, K. T., Subbaraju, G. V., Chien, C. C., \& Chen, Y. C. (2014). Hispolon inhibition of inflammatory apoptosis through reduction of iNOS/NO production via HO-1 induction in macrophages. Journal of Ethnopharmacology, 156, $61-72$

Yayeh, T., Oh, W. J., Park, S. C., Kim, T. H., Cho, J. Y., Park, H. J., Lee, I. K., Kim, S. K., Hong, S. B., Yun, B. S., \& Rhee, M. H. (2012). Phellinus baumii ethyl acetate extract inhibits lipopolysaccharide-induced iNOS, COX-2, and proinflammatory cytokine expression in RAW264.7 cells. Journal of Natural Medicines, 66, 49-54.

Yoon, H. M., Jang, K. J., Han, M. S., Jeong, J. W., Kim, G. Y., Lee, J. H., \& Choi, Y. H. (2013). Ganoderma lucidum ethanol extract inhibits the inflammatory response by suppressing the NF-kappaB and toll-like receptor pathways in lipopolysaccharidestimulated BV2 microglial cells. Experimental and Therapeutic Medicine, 5, 957-63.

Yoon, J. Y., Kim, J. H., Baek, K. S., Kim, G. S., Lee, S. E., Lee, D. Y., Choi, J. H., Kim, S. Y Park, H. B., Sung, G. H, Lee, K. R. Cho, J. Y., Noh, H. J. (2015). A direct protein kinase B targeted anti inflammatory activity of cordycepin from artificially cultured fruit body of Cordyceps militaris. Pharmacognosy Magazine, 11, 477-485.

Yoshikawa, K., Inoue, M., Matsumoto, Y., Sakakibara, C., Miyataka, H., Matsumoto, H., \& Arihara, S. (2005). Lanostane triterpenoids and triterpene glycosides from the fruit body of Fomitopsis pinicola and their inhibitory activity against COX-1 and COX-2. Journal of Natural Products, 68, 69-73.

Yoshikawa, K., Koso, K., Shimomura, M., Tanaka, M.; Yamamoto, H., Imagawa, H., Arihara, S., Hashimoto, T. (2013). Yellow pigments, fomitellanols A and B, and drimane 
sesquiterpenoids, cryptoporic acids $\mathrm{p}$ and $\mathrm{q}$, from Fomitella fraxinea and their inhibitory activity against COX and 5-LO. Molecules, 18, 4181-4191.

Yuan, G., Wahlqvist, M. L., He, G., \& Yang, M. (2006). Natural products and antiinflammatory activity. Asia Pacific Journal of Clinical Nutrition, 15, 143-152.

Zhang, Y, Mills, G. L., \& Nair, M. G. (2002). Cyclooxygenase inhibitory and antioxidant compounds from the mycelia of the edible mushroom Grifola frondosa. Journal of Agricultural and Food Chemistry, 50, 7581-7585.

Zhang, Y., Mills, G. L., \& Nair, M. G. (2003). Cyclooxygenase inhibitory and antioxidant compounds from the fruiting body of an edible mushroom, Agrocybe aegerita. Phytomedicine, 10, 386-390.

Zhou, Y., Chen, S., Ding, R., Yao, W., \& Gao, X. (2014). Inflammatory Modulation Effect of Glycopeptide from Ganoderma capense (Lloyd) Teng. Mediators of Inflammation, 2014, 1- 8 . 


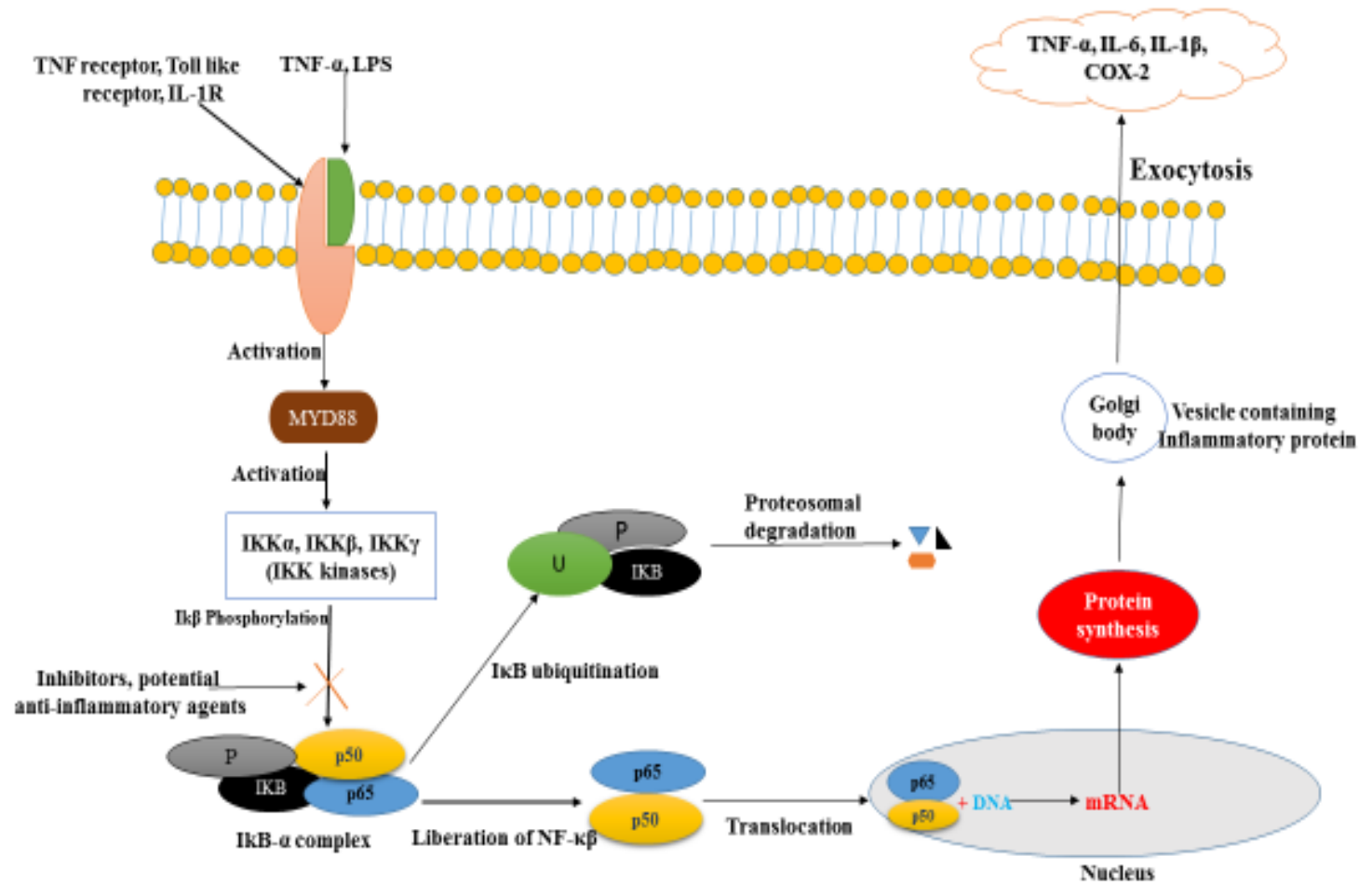

Figure 1. Schematic diagram of nuclear factor- $\kappa \mathrm{B}(\mathrm{NF}-\kappa \mathrm{B})$ pathway. Macrophage cells express membrane receptors such as toll-like receptors (TLRs) and tumor necrosis factor receptors (TNFR). These receptors recognize pro-inflammatory stimuli such as lipopolysaccharides and viral proteins. Attachment of these pathogen-associated molecular patterns (PAMPs) to membrane receptors activates the myeloid differentiation protein 88 (MyD88). MyD88 activates specific protein kinases that are responsible for activation of IKK kinase (IKK $\alpha$, IKK $\beta$, IKK $\gamma$ ). This kinase further phosphorylates IkB- $\alpha$ complex leading to dissociation of the complex, and its proteasomal degradation, allowing NF-kB to translocate to the nucleus, where it binds to specific DNA sequences encoding the pro inflammatory cytokines (e.g., IL-1, IL-2, IL-6, TNF- $\alpha$ as well as Cyclooxygenase-2 (Cox-2) and inducible nitric oxide synthase (iNOS). 


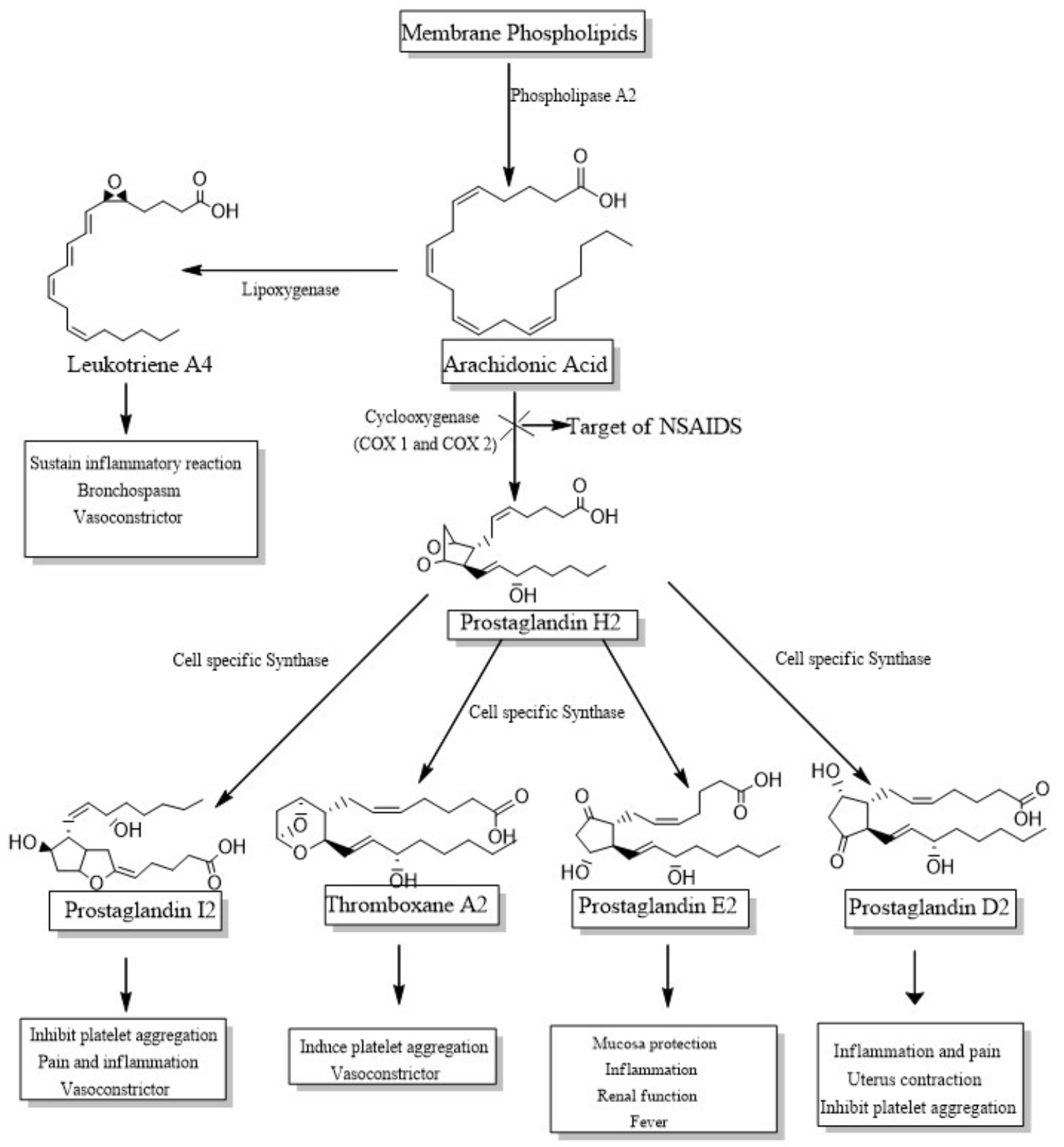

Figure 2. Schematic diagram of the biosynthetic pathway of common prostaglandins. 
Table 1. Previous studies on anti-inflammatory activity of different mushroom species.

\begin{tabular}{|c|c|c|c|c|c|}
\hline Mushroom & Origin & Extract & Assay & Mechanism of action & Reference \\
\hline \multirow[t]{3}{*}{ Agaricus bisporus J.E.Lange } & Spain & Methanol & 1,2 & Inhibited NO production, level of TNF- $\alpha$ released & Moro et al., 2012 \\
\hline & Australia & Ethanol & 1,2 & Reduced level of NO, TNF- $\alpha$ & Gunawardena et al., 2014 \\
\hline & Portugal & Ethanol & 1 & Inhibited NO production & Taofiq et al., 2015 \\
\hline \multirow{4}{*}{$\begin{array}{r}\text { A. bisporus Portobello J.E.Lange } \\
\text { Agaricus blazei Murill }\end{array}$} & Australia & Ethanol & 1,2 & Reduced level of NO, TNF- $\alpha$ & Gunawardena et al., 2014 \\
\hline & Japan & n.m. & 2 & Decreased level of IL-6, IL-8 and IL-10 & Bernardshaw et al., 2006 \\
\hline & Brazil & Water & 4 & Reduced edema & Mourão, et al., 2011 \\
\hline & Korea & Methanol & 2 & Inhibited IL-6, PGD2 release & Song et al., 2012 \\
\hline \multirow{2}{*}{$\begin{array}{r}\text { Amauroderma rugosum (Blume } \\
\& \text { T. Nees) Torrend }\end{array}$} & Malaysia & Ethanol & 1 & Inhibited NO production & Chan et al., 2013 \\
\hline & Malaysia & Ethanol & 1,2 & Inhibited NO production, suppressed TNF- $\alpha$ release & Chan et al., 2015 \\
\hline \multirow{3}{*}{$\begin{array}{r}\text { Antrodia camphorata (M.Zang \& } \\
\text { C.H.Su) Sheng H.Wu, Ryvarden } \\
\& \text { T.T.Chang }\end{array}$} & Taiwan & n.m. & 2 & Inhibited TNF- $\alpha$, IL- $1 \beta$ and NF- $\kappa \beta$ & Hseu et al., 2010 \\
\hline & Taiwan & $\begin{array}{r}\text { Water and } \\
\text { methanol }\end{array}$ & 5 & Inhibited edema & Liu et al., 2007 \\
\hline & Taiwan & n.m. & 1,2 & Reduced NO, TNF- $\alpha \&$ IL- $1 \beta$ production & Hseu et al., 2005 \\
\hline $\begin{array}{r}\text { Antrodia cinnamomea Chang \& } \\
\text { Chou }\end{array}$ & Taiwan & Methanol & 1 & $\begin{array}{r}\text { Inhibited NO, TNF- } \alpha, \text { IL-6 production and COX-2 } \\
\text { expression }\end{array}$ & Wen et al., 2011 \\
\hline $\begin{array}{r}\text { Antrodia salmonea T.T. Chang \& } \\
\text { W.N. Chou }\end{array}$ & Taiwan & Ethanol & $1,2,4$ & Reduced NO and Cytokine release, paw edema inhibition & Huang et al 2012b. \\
\hline Boletus impolitus Fr. & Portugal & Ethanol & 1 & Inhibited NO production & Taofiq et al., 2015 \\
\hline Cantharellus cibarius Fr. & Spain & Methanol & 1,2 & Inhibited NO \& level of TNF- $\alpha$ released & Moro et al., 2012 \\
\hline \multirow[t]{2}{*}{ Cordyceps militaris (L.) Fr. } & Korea & $\begin{array}{r}70 \% \\
\text { Ethanol }\end{array}$ & 3,4 & Inhibited Inflammation & Won et al., 2005 \\
\hline & Korea & Water & 1.2 & Inhibited NO production. IL- 6 and TNF- $\alpha$ inhibition & Joung. et al.. 2014 \\
\hline
\end{tabular}




\begin{tabular}{|c|c|c|c|c|c|}
\hline & & water & & & \\
\hline & Korea & $\begin{array}{l}70 \% \\
\text { ethanol }\end{array}$ & 2 & Reduced expression of TNF- $\alpha$, IL- $1 \beta$ and IL- 6 . & Lim, 2011 \\
\hline Daedalea gibbosa (Pers.) & Israel & $\begin{array}{l}\text { Ethyl } \\
\text { acetate }\end{array}$ & 1,2 & $\begin{array}{l}\text { Reduced level of NO via decreased iNOS promoter } \\
\text { activity, reduced TNF- } \alpha\end{array}$ & Ruimi et al., 2010b \\
\hline $\begin{array}{l}\text { Flammulina velutipes (Curtis) } \\
\text { Singer }\end{array}$ & Australia & Ethanol & 1,2 & Reduced level of NO, TNF- $\alpha$ & Gunawardena et al., 2014 \\
\hline $\begin{array}{l}\text { Ganoderma lucidum (Curtis) P. } \\
\text { Karst. }\end{array}$ & Taiwan & $\begin{array}{l}\text { Water, } \\
80 \% \\
\text { methanol }\end{array}$ & 1 & Reduced level of NO & Chu et al., 2015 \\
\hline & Korea & $\begin{array}{l}25 \% \\
\text { ethanol }\end{array}$ & 1,2 & Inhibited NO, PGE2, IL-1 $\beta$ and TNF- $\alpha$ & Yoon et al., 2013 \\
\hline $\begin{array}{l}\text { Inonotus obliquus (Ach. ex Pers.) } \\
\text { Pilát }\end{array}$ & Korea & $\begin{array}{l}\text { Hot } \\
\text { methanol }\end{array}$ & 1 & Inhibited NO production & Park et al., 2005 \\
\hline & Canada & Ethanol & 1,2 & Inhibited NO production, level of TNF- $\alpha$ released & Van et al., 2009 \\
\hline $\begin{array}{l}\text { Lactarius deliciosus (L. ex Fr.) } \\
\text { S.F.Gray }\end{array}$ & Spain & Methanol & 1,2 & Inhibited NO production, level of TNF- $\alpha$ released & Moro et al., 2012 \\
\hline Lentinus edodes (Berk.) Pegler & Australia & Ethanol & 1,2 & Reduced level of NO, TNF- $\alpha$ & Gunawardena et al., 2014 \\
\hline Lentinus polychrous (L.) Fr. & Thailand & $\begin{array}{l}80 \% \\
\text { Ethanol }\end{array}$ & 1,2 & Inhibited NO \& TNF- $\alpha$ levels, suppressed iNOS activity & Fangkrathok et al., 2013 \\
\hline $\begin{array}{l}\text { Lignosus rhinocerotis (Cooke) } \\
\text { Ryvarden }\end{array}$ & Malaysia & $\begin{array}{l}\text { Water and } \\
\text { methanol }\end{array}$ & 2,4 & Reduced paw swelling, reduced level of TNF- $\alpha$ & Lee et al., 2014 \\
\hline $\begin{array}{l}\text { Macrolepiota procera, (Scop.) } \\
\text { Singer }\end{array}$ & Portugal & Ethanol & 1 & Inhibited NO production & Taofiq et al., 2015 \\
\hline Marasmius oreades (Bolton) Fr & Israel & $\begin{array}{l}\text { Ethyl } \\
\text { acetate }\end{array}$ & 1 & Reduced level of NO & Ruimi et al., 2010a \\
\hline $\begin{array}{l}\text { Naematoloma sublateritium (Fr.) } \\
\text { P. Karst }\end{array}$ & Korea & Ethanol & 2 & Reduced TNF- $\alpha$ release, inhibited NF- $\mathrm{kB}$ activation & Lee et al., 2012 \\
\hline Phellinus baumii Pilát & Korea & Methanol & 1,2 & $\begin{array}{l}\text { Reduced level of NO, inhibited PGE2, } \\
\text { IL-1 } 1 \beta \text {, IL-6 expression }\end{array}$ & Yayeh et al., 2012 \\
\hline $\begin{array}{l}\text { Phellinus linteus (Berk. \& M. A. } \\
\text { Curtis) Teng }\end{array}$ & Korea & $\begin{array}{l}70 \% \\
\text { Ethanol }\end{array}$ & 1 & Decreased iNOS promoter activity and NO production & Kim et al., 2006 \\
\hline & Korea & $\begin{array}{l}70 \% \\
\text { Ethanol }\end{array}$ & 3 & Inhibited inflammation & Kim et al., 2004 \\
\hline & Korea & $\begin{array}{l}70 \% \\
\text { Ethanol }\end{array}$ & 1 & Inhibited NO production & Kim et al., 2007 \\
\hline
\end{tabular}




\begin{tabular}{|c|c|c|c|c|c|}
\hline & Taiwan & n.m. & 1,2 & Inhibited NO and TNF- $\alpha$ production & Lin et al., $2014 \mathrm{~b}$ \\
\hline & Korea & $\begin{array}{l}\text { Ethanol, } \\
\text { Ethyl } \\
\text { acetate }\end{array}$ & 1,2 & Inhibited NO and PGE2 production & Song et al., 2014 \\
\hline Pleurotus eryngii (DC.) Quél. & Taiwan & Ethanol & 1,2 & Reduced level of NO, inhibition of PGE2 release & Lin et al., 2014a \\
\hline \multirow[t]{3}{*}{ Pleurotus florida Singer } & India & Methanol & 4 & Reduced edema & Jose et al., 2004 \\
\hline & Iran & Water & 1 & Reduced level of NO & Ghazanfari et al., 2009 \\
\hline & Korea & $\begin{array}{l}60 \% \\
\text { acetone, } \\
80 \% \\
\text { methanol }\end{array}$ & 1,4 & Reduced level of NO, inhibited edema & Im et al., 2014 \\
\hline $\begin{array}{l}\text { Pleurotus } \\
\text { ostreatoroseus } \text { Singer }\end{array}$ & Brazil & ethanol & 1 & Inhibited NO production & Corrêa et al., 2015 \\
\hline \multirow{3}{*}{$\begin{array}{l}\text { Pleurotus ostreatus (Jacq. ex Fr.) } \\
\text { P.Kumm. }\end{array}$} & Portugal & Ethanol & 1 & Inhibited NO production & Taofiq et al., 2015 \\
\hline & Australia & Ethanol & 1,2 & Reduced level of NO, TNF- $\alpha$ & Gunawardena et al., 2014 \\
\hline & USA & Water & 2 & Inhibited production of TNF- $\alpha$, IL- 6 , and IL-12 & Jedinak et al., 2011 \\
\hline Pleurotus sajor-caju (Fr.) Singer & Malaysia & $\begin{array}{l}95 \% \\
\text { ethanol }\end{array}$ & 1 & Reduced level of NO & Saad et al., 2014 \\
\hline $\begin{array}{l}\text { Pleurotus tuber-regium (Rumph. } \\
\text { ex Fr.) Singer }\end{array}$ & Belgium & $\begin{array}{l}95 \% \\
\text { ethanol }\end{array}$ & 1,2 & Reduced level of NO, Inhibit TNF- $\alpha$, and IL- 6 release & Liu et al., 2014 \\
\hline Polyporus dermoporus Pers. & Brazil & Ethanol & $1,3,4$ & Inhibited edema, reduced level of NO & Dore et al., 2014 \\
\hline Poria cocos F.A.Wolf & Korea & Ethanol & 1,2 & $\begin{array}{l}\text { Inhibited NO, PGE2, TNF- } \alpha \text {, and IL- } 1 \beta \text { production, } \\
\text { suppressed NF-kB activity }\end{array}$ & Jeong et al., 2014 \\
\hline Russula virescens (Schaeff.) Fr. & Korea & $\begin{array}{l}70 \% \\
\text { ethanol }\end{array}$ & 1,2 & $\begin{array}{l}\text { Reduced level of NO and inhibition of TNF- } \alpha \text { mRNA } \\
\text { expression }\end{array}$ & Hur et al., 2012 \\
\hline $\begin{array}{l}\text { Termitomyces albuminosus } \\
\text { (Berk.) R.Heim }\end{array}$ & China & $\begin{array}{l}80 \% \\
\text { Ethanol }\end{array}$ & 4,6 & Reduced edema & Lu et al., 2008 \\
\hline
\end{tabular}




\begin{tabular}{|c|c|c|c|c|c|}
\hline Tremella fuciformis Berk. & Korea & $\begin{array}{l}80 \% \\
\text { methanol }\end{array}$ & 1 & Reduced iNOS expression and NO production & Li et al., 2014a \\
\hline Tricholoma matsutake Sing & Korea & $\begin{array}{l}\text { Dichlorom } \\
\text { ethane }\end{array}$ & 1 & Inhibited NO production & Lim et al., 2007 \\
\hline Tuber aestivum Vittad. & Serbia & Methanol & 7 & Inhibited COX-1 activity & Beara et al., 2014 \\
\hline Tuber magnatum Pico & Serbia & Methanol & 7 & Inhibited COX-1 activity & Beara et al., 2014 \\
\hline
\end{tabular}

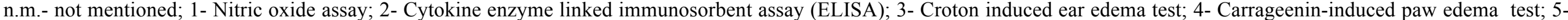
TPA (12-O-tetradecanoylphorbol-13-acetate) induced ear edema; 6- Xylene induced edema. 7- COX-1- and COX-2-Catalyzed prostaglandin biosynthesis assay in vitro. 
Table 2. Polysaccharides isolated from mushrooms with reported anti-inflammatory activity.

\begin{tabular}{|c|c|c|c|c|c|c|}
\hline Mushroom & Origin & Bioactive compound & Extraction solvent & Assay & Mechanism of action & Reference \\
\hline \multirow{2}{*}{$\begin{array}{l}\text { Agaricus bisporus } \\
\text { J.E.Lange }\end{array}$} & Brazil & Fucogalactan & Water, ethanol & 5 & Decreased iNOS and COX-2 expression & Ruthes et al., 2013b \\
\hline & Brazil & Fucogalactan & $\begin{array}{l}\text { Chloroform, } \\
\text { methanol }\end{array}$ & 7 & $\begin{array}{l}\text { Inhibited acetic acid induced } \\
\text { inflammation }\end{array}$ & Komura et al., 2010 \\
\hline Agaricus blazei Murill & China & Soluble polysaccharide & Water & 2 & $\begin{array}{l}\text { Inhibited TNF- } \alpha \text {, IL-1 } \beta, \text { COX-2, iNOS, } \\
\text { and ICAM-1 Levels }\end{array}$ & Wang et al., 2013b \\
\hline Agaricus brasiliensis Peck & Brazil & Fucogalactan & $\begin{array}{l}\text { Chloroform, } \\
\text { methanol }\end{array}$ & 7 & $\begin{array}{l}\text { Inhibited acetic acid induced } \\
\text { inflammation }\end{array}$ & Komura et al., 2010 \\
\hline Agrocybe chaxingu Huaag & Korea & $\beta$-Glucan & n.m. & 1,6 & $\begin{array}{l}\text { Inhibited NO production and edema } \\
\text { formation }\end{array}$ & Lee et al., 2009 \\
\hline $\begin{array}{l}\text { Amanita muscaria (L.) } \\
\text { Lam. }\end{array}$ & Brazil & Fucomannogalactan & $\begin{array}{l}\text { Hot, cold water and } \\
\text { aq. } \mathrm{KOH}\end{array}$ & 5 & $\begin{array}{l}\text { Reduced formalin-induced inflammatory } \\
\text { pain }\end{array}$ & Ruthes et al., 2013c \\
\hline $\begin{array}{l}\text { Armillariella mellea } \\
\text { (Vahl) P.Kumm. }\end{array}$ & Taiwan & $\begin{array}{l}\text { Polysaccharides and } \\
\text { sulphated } \\
\text { polysaccharides }\end{array}$ & $\begin{array}{l}\text { Hot water, } 95 \% \\
\text { ethanol }\end{array}$ & 2 & Inhibited TNF- $\alpha$ and IL- 6 secretion & Chang et al., 2013 \\
\hline \multirow[t]{2}{*}{$\begin{array}{l}\text { Caripia montagnei (Berk.) } \\
\text { Kuntze }\end{array}$} & Brazil & $\beta$-Glucan & $\begin{array}{l}\text { chloroform- } \\
\text { methanol }(1: 1, \mathrm{v} / \mathrm{v}) \\
80 \% \text { acetone }\end{array}$ & 1,3 & $\begin{array}{l}\text { Inhibited NO production, edema } \\
\text { inhibition }\end{array}$ & Castro et al., 2014 \\
\hline & Brazil & $\beta$-Glucan & $80 \%$ acetone & $1,2,3$ & $\begin{array}{l}\text { Inhibited NO production, decreased } \\
\text { cytokine release, edema reduction }\end{array}$ & Queiroz et al., 2010 \\
\hline \multirow{3}{*}{$\begin{array}{l}\text { Collybia dryophila } \\
\text { (Bull.) P. Kumm. } \\
\text { Cordyceps militaris (L.) } \\
\text { Fr. }\end{array}$} & Canada & $\begin{array}{l}(1 \rightarrow 3),(1 \rightarrow 4) \\
\beta \text {-Glucans }\end{array}$ & $85 \%$ ethanol & 1 & Inhibited NO production & $\begin{array}{l}\text { Pacheco-Sanchez et al., } \\
2006\end{array}$ \\
\hline & Taiwan & $\begin{array}{l}\text { Glucose, D-mannitol, } \\
\text { 3,4-O-isopropylidene- } \\
\text { D-mannitol }\end{array}$ & Methanol & 1,2 & $\begin{array}{l}\text { Inhibited NO production, decreased } \\
\text { cytokine release }\end{array}$ & Rao et al., 2010 \\
\hline & Korea & $(1-3)-\beta-D-G l u c a n$ & $\begin{array}{l}\text { Chloroform- } \\
\text { methanol }\end{array}$ & 2 & Inhibited IL- $1 \beta$, TNF- $\alpha, \mathrm{COX}-2$ release. & Smiderle et al., 2014 \\
\hline Geastrum saccatum Fr. & Brazil & $\beta$-Glucan & $\begin{array}{l}\text { Acetone, water, } \\
\text { ethanol }\end{array}$ & $1,3,6$ & $\begin{array}{l}\text { Reduced nitrate/ nitrite and interleukin } \\
\text { level }\end{array}$ & Dore et al., 2007 \\
\hline Lactarius rufus (Scop.) Fr. & Brazil & $\begin{array}{l}(1 \rightarrow 3),(1 \rightarrow 6)-\beta-D- \\
\text { Glucans }\end{array}$ & Water, ethanol & 5 & Inhibited pain & Ruthes et al., 2013a \\
\hline
\end{tabular}




\begin{tabular}{|c|c|c|c|c|c|c|}
\hline \multirow[t]{3}{*}{$\begin{array}{l}\text { Lentinus edodes (Berk.) } \\
\text { Pegler }\end{array}$} & Japan & $\beta$-Glucan & n.m. & 1,2 & $\begin{array}{l}\text { Inhibited NO production, level of TNF- } \alpha \\
\text { released }\end{array}$ & Xu et al., 2012 \\
\hline & Japan & Lentinan & n.m. & 2 & Down regulated IL-8 mRNA expression & Mizuno et al., 2009 \\
\hline & Brazil & Heterogalactan & Water & 7 & $\begin{array}{l}\text { Inhibited acetic acid-induced } \\
\text { inflammation }\end{array}$ & Carbonero et al., 2008 \\
\hline \multirow{3}{*}{$\begin{array}{l}\text { Pleurotus pulmonarius } \\
\text { (Fr.) Quél. }\end{array}$} & Israel & Glucan & Water, Ethanol & 2 & Inhibited TNF- $\alpha$ released from cells & Lavi et al., 2010 \\
\hline & Nigeria & $\beta$-D-Glucan & $95 \%$ Acetone & 3 & Inhibited edema formation & Adebayo et al., 2012 \\
\hline & Brazil & $(1 \rightarrow 3),(1 \rightarrow 6) \beta$-glucan & $\begin{array}{l}\text { chloroform- } \\
\text { methanol }\end{array}$ & 7 & Inhibited induced inflammation & Smiderle et al., 2008 \\
\hline \multirow[t]{2}{*}{$\begin{array}{l}\text { Pleurotus sajor-caju (Fr.) } \\
\text { Singer }\end{array}$} & Brazil & $\beta$-D-Glucan & $\begin{array}{l}\text { chloroform- } \\
\text { methanol }(2: 1, \mathrm{v} / \mathrm{v}) \text {, } \\
\text { water and ethanol }\end{array}$ & 2 & $\begin{array}{l}\text { Inhibited production of pro- } \\
\text { inflammatory genes }\end{array}$ & Silveira et al., 2014 \\
\hline & Brazil & Exopolysaccharide & Ethanol & 3 & Reduced edema & Silveira et al., 2015 \\
\hline $\begin{array}{l}\text { Scleroderma nitidum } \\
\text { Berk. }\end{array}$ & Brazil & $\beta$-Glucan & $80 \%$ acetone & $1,2,3$ & $\begin{array}{l}\text { Reduced level of NO, IFN- } \gamma \text {, IL-2, IL- } \\
10 \text {, suppresed paw edema }\end{array}$ & Nascimento et al., 2012 \\
\hline $\begin{array}{l}\text { Termitomyces } \\
\text { albuminosus (Berk.) } \\
\text { R.Heim }\end{array}$ & China & Crude polysaccharide & $80 \%$ Ethanol, water & $3,4,5$ & Inhibition of edema formation & Lu et al., 2008 \\
\hline
\end{tabular}


Table 3. Terpenes isolated from mushrooms with reported anti-inflammatory activity.

\begin{tabular}{|c|c|c|c|c|c|c|}
\hline Mushroom & Origin & Bioactive compound & Extraction solvent & Assay & Mechanism of action & Reference \\
\hline $\begin{array}{l}\text { Antrodia camphorata } \\
\text { (M.Zang \& C.H.Su) Sheng } \\
\text { H.Wu, Ryvarden \& } \\
\text { T.T.Chang }\end{array}$ & Taiwan & $\begin{array}{l}\text { Eburicoic acid } \\
\text { Dehydroeburicoic acid }\end{array}$ & Methanol & $1,2,5$ & $\begin{array}{l}\text { Inhibited NO production and } \\
\text { cytokine release; Suppressed } \\
\text { Carrageenin -induced edema }\end{array}$ & Deng et al., 2013 \\
\hline $\begin{array}{l}\text { Cyathus africanus } \mathrm{H} . \mathrm{J} . \\
\text { Brodie }\end{array}$ & China & Diterpenoid & Ethyl acetate & 1 & Inhibited NO production & Han et al., 2013 \\
\hline Cyathus hookeri Berk. & China & Cyathane diterpenoid & Ethanol & 1 & Inhibited NO production & $\mathrm{Xu}$ et al., 2013 \\
\hline $\begin{array}{l}\text { Fomitella fraxinea (Bull.) } \\
\text { Imazeki }\end{array}$ & Japan & $\begin{array}{l}\text { Fomitellanols,cryptopo } \\
\text { ric acids, }\end{array}$ & Isopropanol & 3 & Inhibited COX-1 activit & Yoshikawa et al., 2013 \\
\hline $\begin{array}{l}\text { Fomitopsis nigra (Berk.) } \\
\text { Imaz. }\end{array}$ & Korea & Pachymic acid & Methanol & 2 & $\begin{array}{l}\text { Inhibition of ICAM-1, Cox-2, and } \\
\text { iNOS expression }\end{array}$ & Lee et al., 2013 \\
\hline $\begin{array}{l}\text { Fomitopsis pinicola }(\mathrm{Sw} .: \mathrm{Fr} .) \\
\text { P. Karst. }\end{array}$ & Japan & $\begin{array}{l}\text { Lanostane } \\
\text { triterpenoids, triterpene } \\
\text { glycosides }\end{array}$ & $70 \%$ Ethanol & 3 & Inhibited COX-2 activity & Yoshikawa et al., 2005 \\
\hline \multirow[t]{5}{*}{$\begin{array}{l}\text { Ganoderma lucidum (Curtis) } \\
\text { P. Karst. }\end{array}$} & Korea & Lanostane triterpenes & $\begin{array}{l}\text { Water and ethyl } \\
\text { acetate }\end{array}$ & 1,2 & $\begin{array}{l}\text { Inhibited NO production; suppressed } \\
\text { iNOS and COX-2 expression }\end{array}$ & Choi et al., 2014a Lee \\
\hline & USA & Triterpene & $95 \%$ ethanol & 1,2 & $\begin{array}{l}\text { Inhibited TNF- } \alpha, \mathrm{PGE}_{2} \text { and } \mathrm{NO} \\
\text { production; suppressed IL-6 } \\
\text { production }\end{array}$ & Dudhgaonkar et al., 2009 \\
\hline & Japan & Triterpene acids & Methanol & 4 & Suppressed TPA-induced edema & Akihisa et al., 2007 \\
\hline & Japan & Triterpene butyl esters & Methanol & & $\begin{array}{l}\text { Inhibited NO production; suppressed } \\
\text { iNOS and COX-2 activity }\end{array}$ & Tung et al., 2013 \\
\hline & China & Ganoderic acid C1 & Methylene chloride & 2 & Inhibited TNF- $\alpha$ production & Liu et al., 2015 \\
\hline $\begin{array}{l}\text { Inonotus obliquus (Ach. ex } \\
\text { Pers.) Pilát }\end{array}$ & China & Triterpenes & Ethanol & 1 & Inhibited NO production & Ma et al., 2013 \\
\hline $\begin{array}{l}\text { Laetiporus sulphureus (Bull.) } \\
\text { Murrill }\end{array}$ & Korea & Acetyl Eburicoic Acid & Methanol & 1 & Inhibited NO production & Saba et al., 2015 \\
\hline \multirow[t]{2}{*}{$\begin{array}{l}\text { Piptoporus betulinus (Bull. ex } \\
\text { Fr.) P. Karst. }\end{array}$} & Germany & Lanostanoids & $\begin{array}{l}\text { Ethyl acetate, } \\
\text { chloroform, } \\
\text { methanol }\end{array}$ & 3 & Inhibited COX-1 activity & Kemami et al., 2004 \\
\hline & Japan & $\begin{array}{l}\text { Lanostane-Type } \\
\text { Triterpene }\end{array}$ & Methanol & 4 & Suppressed TPA-induced edema & Kamo et al., 2003 \\
\hline Poria cocos F.A.Wolf & China & $\begin{array}{l}\text { 29-hydroxypolyporenic } \\
\text { acid C, polyporenic }\end{array}$ & $70 \%$ ethanol & 1 & Inhibited NO production & Cai \& Cai, 2011 \\
\hline
\end{tabular}




\begin{tabular}{|c|c|c|c|c|c|c|}
\hline \multirow{2}{*}{$\begin{array}{l}\text { Sarcodon scabrosus (Fr.), P. } \\
\text { Karst. }\end{array}$} & Japan & Cyathane diterpenoid & Methanol & 4 & $\begin{array}{l}\text { Suppressed TPA-induced } \\
\text { inflammation }\end{array}$ & Hirota et al., 2002 \\
\hline & Japan & Diterpenoid & Methanol & 4 & Suppressed TPA-induced & Kamo et al., 2004 \\
\hline
\end{tabular}

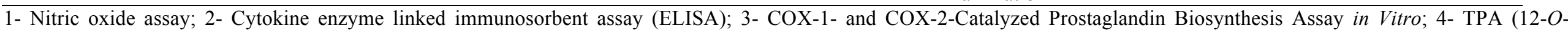
tetradecanoylphorbol-13-acetate) induced ear edema; 5-Carrageenin-induced paw edema. 
Table 4. Phenolic compounds and derivatives isolated from mushrooms with reported anti-inflammatory potential.

\begin{tabular}{|c|c|c|c|c|c|c|}
\hline Mushroom & Origin & Bioactive compound & Extraction solvent & Assay & Mechanism of action & Reference \\
\hline Agaricus bisporus J.E.Lange & Japan & $\begin{array}{l}\text { 2-Amino-3H- } \\
\text { phenoxazin-3-one }\end{array}$ & Ethyl acetate & 1,23 & $\begin{array}{l}\text { Inhibited NO, COX1 and COX } 2 \\
\text { activity and cytokine release }\end{array}$ & Kohno et al., 2008 \\
\hline $\begin{array}{l}\text { Albatrellus caeruleoporus } \\
\text { (Peck) Pouzar }\end{array}$ & Japan & Grifolin dervatives & Methanol & 1 & Reduced NO production & Quang et al., 2006b \\
\hline \multirow{4}{*}{$\begin{array}{l}\text { Antrodia camphorata (M.Zang } \\
\text { \& C.H.Su) Sheng H.Wu, } \\
\text { Ryvarden \& T.T.Chang }\end{array}$} & Taiwan & Benzenoids & $\begin{array}{l}\text { Ethylacetate, } \\
\text { methanol }\end{array}$ & 1 & Inhibited NO production & Chen et al., 2013 \\
\hline & Taiwan & $\begin{array}{l}\text { Antrocamphin A } \\
\text { (Benzenoids) }\end{array}$ & $\begin{array}{l}95 \% \text { Ethanol, ethyl } \\
\text { acetate, water }\end{array}$ & 1,2 & $\begin{array}{l}\text { Inhibited NO production, Down- } \\
\text { regulated iNOS } \\
\text { and COX- } 2 \text { expression }\end{array}$ & Hsieh et al., 2010 \\
\hline & Taiwan & $\begin{array}{l}\text { Antrocamphin A and } \\
\text { its analogue }\end{array}$ & n.m & & Inhibited NO production & Lee et al., 2011 \\
\hline & Taiwan & Benzocamphorin & Ethanol & 1 & Inhibited NO production & Liao et al., 2012 \\
\hline Daedalea quercina (L.) Pers. & Germany & Quercinol & n.m & 2 & Inhibited COX 2 enzyme activity & Gebhardt et al., 2007 \\
\hline $\begin{array}{l}\text { Daldinia childiae Ces. \& De } \\
\text { Not. }\end{array}$ & Japan & $\begin{array}{l}\text { Benzophenone } \\
\text { derivatives }\end{array}$ & n.m & 1 & Supressed NO production & Quang et al., 2006a \\
\hline Elaphomyces granulatus Fr. & USA & $\begin{array}{l}\text { Syringaldehyde } \\
\text { and syringic acid }\end{array}$ & $95 \%$ Ethanol & 2 & Inhibited COX-2 activity & Stanikunaite et al., 2009 \\
\hline Grifola gargal Singer & Japan & Ergothioneine & hot water & 3 & $\begin{array}{l}\text { Inhibited TNF- } \alpha \text {-induced IL- } 6 \\
\text { release }\end{array}$ & Ito et al., 2011 \\
\hline \multirow[t]{2}{*}{$\begin{array}{l}\text { Inonotus xeranticus (Berk.) } \\
\text { Imazeki \& Aoshima }\end{array}$} & Korea & Davallialactone & n.m & 1,3 & $\begin{array}{l}\text { Inhibited NO production and } \\
\text { cytokine release }\end{array}$ & Lee et al., 2008 \\
\hline & Korea & Davallialactone & n.m & 3 & $\begin{array}{l}\text { Inhibition of ICAM-1, COX-2, and } \\
\text { iNOS expression }\end{array}$ & Lee et al., 2011a \\
\hline $\begin{array}{l}\text { Neolentinus lepideus (Fr.) } \\
\text { Redhead \& Ginns }\end{array}$ & China & $\begin{array}{l}\text { Benzoquinone, } \\
\text { cinnamic acid } \\
\text { derivatives }\end{array}$ & Ethyl acetate & 1 & Inhibited NO production & Li et al., 2013 \\
\hline Phellinus gilvus (Schwein.) Pat & Korea & protocatechualdehyde & Water & 1 & $\begin{array}{l}\text { Inhibited NO production, inhibited } \\
\text { iNOS, COX-2 expression }\end{array}$ & Chang et al., 2011b \\
\hline $\begin{array}{l}\text { Phellinus linteus (Berk. \& M. } \\
\text { A. Curtis) Teng }\end{array}$ & Taiwan & Inotilone & $95 \%$ Ethanol & 1,34 & $\begin{array}{l}\text { Inhibited NO, cytokines and MAPK } \\
\text { Activation; suppressed edema. }\end{array}$ & Huang et al., 2012 \\
\hline
\end{tabular}




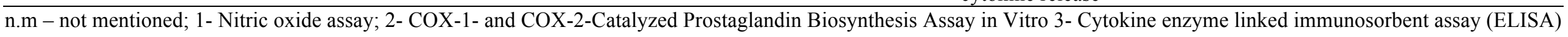


Table 5. Common steroids isolated from mushrooms with reported anti-inflammatory activity.

\begin{tabular}{|c|c|c|c|c|c|c|}
\hline Mushroom & Origin & $\begin{array}{l}\text { Bioactive } \\
\text { compound }\end{array}$ & $\begin{array}{l}\text { Extraction } \\
\text { solvent }\end{array}$ & Assay & $\begin{array}{l}\text { Mechanism of } \\
\text { action }\end{array}$ & Reference \\
\hline \multirow[t]{3}{*}{$\begin{array}{l}\text { Antrodia camphorata (M.Zang \& } \\
\text { C.H.Su) Sheng H.Wu, Ryvarden } \\
\& \text { T.T.Chang }\end{array}$} & Taiwan & Ergostatrien-3 $\beta$-ol & $\begin{array}{l}\text { Methanol, } \\
\text { ethyl } \\
\text { acetate }\end{array}$ & $1,2,3$ & $\begin{array}{l}\text { Decreased IL- } 1 \beta \text { and TNF- } \alpha \text { release; } \\
\text { inhibited NO and reduced edema }\end{array}$ & Huang et al., 2010 \\
\hline & Taiwan & Zhankuic acid C & n.m & 2 & Decreased TNF- $\alpha$, IL-6, IL-12 & Lin et al., 2015 \\
\hline & Taiwan & Zhankuic acid A & n.m & 2 & $\begin{array}{l}\text { Inhibited TNF- } \alpha \text { and IL- } 6 \text { levels, inhibits } \\
\text { iNOS, COX } 2 \text { expression }\end{array}$ & Chen et al., 2014 \\
\hline Cordyceps militaris (L.) Fr. & Taiwan & Ergosterol & Methanol & 1,2 & $\begin{array}{l}\text { Inhibited NO production, decreased } \\
\text { cytokine release }\end{array}$ & Rao et al., 2010 \\
\hline $\begin{array}{l}\text { Ganoderma lucidum (Curtis) P. } \\
\text { Karst }\end{array}$ & India & $\begin{array}{l}\text { Ergosta-7,22-diene- } 3 \beta \text { - } \\
\text { yl pentadecanoate }\end{array}$ & $\begin{array}{l}\text { Petroleum } \\
\text { ether, } \\
\text { chloroform }\end{array}$ & 3 & Suppressed edema & Joseph et al., 2011 \\
\hline \multirow{3}{*}{$\begin{array}{l}\text { Grifola frondosa (Dicks.) Gray } \\
\text { Hericium erinaceum (Bull.) } \\
\text { Persoon }\end{array}$} & Taiwan & Ergosterol peroxide & n-hexane & 2 & Inhibited IL-1 $\beta$, IL- 6 and TNF- $\alpha$ & Wu et al., 2013 \\
\hline & Korea & Hericirine (ergosterol) & Methanol & 1,2 & $\begin{array}{l}\text { Inhibited NO production and cytokine } \\
\text { release }\end{array}$ & Li et al., 2014 \\
\hline & Korea & Ergostane-type sterol & Methanol & 1,2 & $\begin{array}{l}\text { Inhibited NO production and release of } \\
\text { TNF- } \alpha\end{array}$ & Li et al., 2015 \\
\hline $\begin{array}{l}\text { Inonotus obliquus (Ach. ex Pers.) } \\
\text { Pilát }\end{array}$ & China & $\begin{array}{l}\text { Ergosterol, ergosterol } \\
\text { peroxide, trametenolic } \\
\text { acid }\end{array}$ & Ethanol & 1 & Inhibited NO production & Ma et al., 2013 \\
\hline $\begin{array}{l}\text { Pleurotus tuber-regium (Rumph. } \\
\text { ex Fr.) Singer }\end{array}$ & $\begin{array}{l}\text { Belgiu } \\
\mathrm{m}\end{array}$ & $\begin{array}{l}\text { Cerevisterol, ergosta } \\
4,6,8(14), 22 \text {-tetraen-3- } \\
\text { one }\end{array}$ & $\begin{array}{l}95 \% \\
\text { Ethanol }\end{array}$ & 1,2 & $\begin{array}{l}\text { Inhibited NO and TNF- } \alpha \text {, iNOS,COX2 } \\
\text { expression was inhibited }\end{array}$ & Liu et al., 2014 \\
\hline Sarcodon aspratus (Berk.) & Japan & $\begin{array}{l}\text { Ergosterol, ergosterol } \\
\text { peroxide, } 9,11 \text {-dehydro } \\
\text { ergosterol peroxide }\end{array}$ & Acetone & 2 & $\begin{array}{l}\text { Decreased TNF- } \alpha \text { level, reduced NF-kB } \\
\text { activity }\end{array}$ & Kobori et al., 2007 \\
\hline
\end{tabular}


Table 6. Other compounds isolated from mushrooms with reported anti-inflammatory activity.

\begin{tabular}{|c|c|c|c|c|c|c|}
\hline Mushroom & Origin & Bioactive compound & $\begin{array}{l}\text { Extraction } \\
\text { solvent }\end{array}$ & Assay & Mechanism of action & Reference \\
\hline $\begin{array}{l}\text { Agrocybe aegerita (V. Brig.) } \\
\text { Singer }\end{array}$ & USA & Fatty acids & Methanol & 1 & Inhibited COX-II enzyme activity & Zhang et al., 2003 \\
\hline $\begin{array}{l}\text { Antrodia camphorata (M.Zang \& } \\
\text { C.H.Su) Sheng H.Wu, Ryvarden \& } \\
\text { T.T.Chang }\end{array}$ & Taiwan & $\begin{array}{l}\text { Succinic and } \\
\text { maleic derivatives }\end{array}$ & Methanol & 3 & Decreased IL- $1 \beta$ and TNF- $\alpha$ release & Chien et al., 2008 \\
\hline \multirow[t]{3}{*}{$\begin{array}{l}\text { Antrodia cinnamomea } \text { Chang \& } \\
\text { Chou }\end{array}$} & China & $\begin{array}{l}\text { Maleimide and Maleic } \\
\text { Anhydride }\end{array}$ & Methanol & 2 & Inhibited NO production & Wu et al., 2008 \\
\hline & Taiwan & Maleimide Derivatives & $95 \%$ Ethanol & 2 & Inhibited NO production & Wu et al., 2013b \\
\hline & Taiwan & Antrodan (glycoprotein) & $\begin{array}{l}\text { Double- } \\
\text { distilled water }\end{array}$ & 2 & Inhibited NO production & Chiu et al., 2014 \\
\hline Coprinus comatus (O.F.Müll.) Pers & China & Triglycerides & Acetone & 3 & TNF- $\alpha$, IL-1 $\beta$ Inhibition & Ren et al., 2012 \\
\hline Cordyceps cicadae & Taiwan & $\begin{array}{l}\mathrm{N}^{6}-(2- \\
\text { Hydroxyethyl)adenosine } \\
\text { cordycepin, adenosine }\end{array}$ & Ethanol & 3 & Inhibited production of cytokines & Lu et al., 2015 \\
\hline \multirow[t]{3}{*}{$\begin{array}{l}\text { Cordyceps militaris } \\
\text { (L.) Fr. }\end{array}$} & Korea & Cordycepin & n.m & 2,3 & $\begin{array}{l}\text { Inhibited NO production and cytokine } \\
\text { release }\end{array}$ & Jeong et al., 2010 \\
\hline & Taiwan & Cordycepin & Methanol & 2,3 & $\begin{array}{l}\text { Inhibited NO production; Decreased } \\
\text { cytokine release }\end{array}$ & Rao et al., 2010 \\
\hline & Korea & $\begin{array}{l}\text { Cordycepin, } \alpha- \\
\text { Dimorphecolic acid }\end{array}$ & $70 \%$ ethanol & 2,3 & Inhibited NO and PGE2 production & Yoon et al., 2015 \\
\hline Cordyceps sinensis (Berk.) Sacc. & China & cordymin & Water & 3,5 & $\begin{array}{l}\text { Decreased IL- } 1 \beta \text { and TNF- } \alpha \text { level, } \\
\text { inhibition of acetic acid-induced } \\
\text { constriction }\end{array}$ & Qian et al., 2012 \\
\hline $\begin{array}{l}\text { Fomes fomentarius } \\
\text { (L.) Fr. }\end{array}$ & Korea & $\begin{array}{l}\text { Methyl 9-Oxo- } \\
(10 \mathrm{E}, 12 \mathrm{E})- \\
\text { octadecadienoate }\end{array}$ & Methanol & 2,3 & $\begin{array}{l}\text { Decreased iNOS expression; Inhibited } \\
\text { TNF- } \alpha \text { production }\end{array}$ & Choe et al., 2015 \\
\hline Ganoderma capense (Lloyd) Teng & China & Glycopeptide & n.m & 2 & Inhibited NO production & Zhou et al., 2014 \\
\hline
\end{tabular}




\begin{tabular}{|c|c|c|c|c|c|c|}
\hline $\begin{array}{l}\text { Grifola frondosa } \\
\text { (Dicks.) Gray }\end{array}$ & China & Agaricoglycerides & $\begin{array}{l}\text { Ethyl acetate, } \\
\text { acetone }\end{array}$ & 3 & $\begin{array}{l}\text { Decreased IL- } 1 \beta \text { and TNF- } \alpha \text {; } \\
\text { inhibited ICAM- } 1 \text {, iNOS, and COX- } 2 \\
\text { expression }\end{array}$ & Han et al., 2012 \\
\hline & USA & Fatty acid fraction & $\begin{array}{l}\text { Hexane, ethyl } \\
\text { acetate, } \\
\text { methanol }\end{array}$ & 1 & $\begin{array}{l}\text { Inhibited COX } 1 \text { and COX } 2 \text { enzyme } \\
\text { activity }\end{array}$ & Zhang et al., 2002 \\
\hline $\begin{array}{l}\text { Lignosus rhinocerotis } \\
\text { (Cooke) Ryvarden }\end{array}$ & Malaysia & $\begin{array}{l}\text { Polysaccharide- } \\
\text { Protein complexes }\end{array}$ & $\begin{array}{l}\text { Hot, cold } \\
\text { Methanol }\end{array}$ & $\begin{array}{l}3 \\
4\end{array}$ & $\begin{array}{l}\text { Inhibited TNF- } \alpha \text { production; reduced } \\
\text { carrageenin-induced edema }\end{array}$ & Lau et al., 2015 \\
\hline Pleurotus citrinopileatus Singer & Taiwan & Nonlectin glycoprotein & n.m & 2,3 & Inhibited NO and PGE2 & Chen et al., 2011 \\
\hline
\end{tabular}

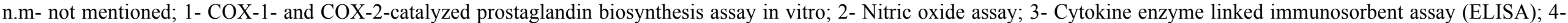
Carrageenin-induced paw edema test; 5 - Acetic acid induced inflammation test 
Table 7. Synthesised and commercial compounds with reported anti-inflammatory activity.

\begin{tabular}{|c|c|c|c|c|}
\hline Compounds & Type & Assay & Mechanism of action & Refrences \\
\hline Cinnamic acid, $p$-hydroxybenzoic acid, $p$-coumaric acid & Commercial & 1 & Inhibited NO production & Taofiq et al., 2015 \\
\hline Glucuronated $p$-coumaric acid, methylated $p$-coumaric acid & Synthesised & 1 & Inhibited NO production & Taofiq et al., 2015 \\
\hline Glucuronated cinnamic acid, methylated cinnamic acid & Synthesised & 1 & Inhibited NO production & Taofiq et al., 2015 \\
\hline $\begin{array}{l}\text { Methylated } p \text {-hydroxybenzoic acid, glucuronated } p \text { - } \\
\text { hydroxybenzoic acid }\end{array}$ & Synthesised & 1 & Inhibited NO production & Taofiq et al., 2015 \\
\hline \multirow[t]{4}{*}{ Cordycepin } & Commercial & 1,2 & $\begin{array}{l}\text { Reduced NO, TNF- } \alpha \text { and IL- } 1 \beta \text {, } \\
\text { suppressed phosphorylation of } \\
\text { MAPKs }\end{array}$ & Choi et al., 2014b \\
\hline & Commercial & 1 & Reduced NO production & Imamura et al., 2015 \\
\hline & Commercial & 1,2 & $\begin{array}{l}\text { Inhibited NO production and } \\
\text { cytokine release }\end{array}$ & Jeong et al., 2010 \\
\hline & Commercial & 1,2 & $\begin{array}{l}\text { Inhibited NO production, } \\
\text { decreased IL-1 } \beta \text {, IL- } 6 \text {, TNF- } \alpha \\
\text { release }\end{array}$ & Shin et al., 2009 \\
\hline Ethynylbenzenoid & Synthesized & 2 & $\begin{array}{l}\text { Down-regulated TNF- } \alpha \\
\text { expression }\end{array}$ & Buccini et al., 2014 \\
\hline Ergosterol & Commercial & & $\begin{array}{l}\text { Inhibited NO production and } \\
\text { cytokine release }\end{array}$ & Kuo et al., 2011 \\
\hline Hispidin & Commercial & 2 & $\begin{array}{l}\text { Suppressed NF- } \boldsymbol{\kappa} \text { B activity, } \\
\text { induced } \mathrm{I} \kappa \mathrm{B} \text { degradation }\end{array}$ & Shao et al., 2015 \\
\hline \multirow[t]{2}{*}{ Hispolon } & Synthesized & $1,2,3$ & $\begin{array}{l}\text { Inhibited NO production, TNF- } \alpha \\
\text { release; reduced edema }\end{array}$ & Chang et al., 2011a \\
\hline & Commercial & 1 & $\begin{array}{l}\text { Inhibition of NO production and } \\
\text { iNOS expression }\end{array}$ & Yang et al 2014 \\
\hline Inotilone and methylinotilone & Synthesized & 1,2 & $\begin{array}{l}\text { Decreased nitrite and } \\
\text { prostaglandin level }\end{array}$ & Kuo et al., 2009 \\
\hline
\end{tabular}

1-Nitric oxide assay; 2- Cytokine enzyme linked immunosorbent assay (ELISA); 3-Carrageenin-induced paw edema test. 